\title{
Ubiquitin C-terminal hydrolase-L1 increases cancer cell invasion by modulating hydrogen peroxide generated via NADPH oxidase 4
}

\author{
Hyun Jung Kim¹, Venkataraman Magesh ${ }^{1}$, Jae-Jin Lee ${ }^{1}$, Sun Kim¹, Ulla G. Knaus ${ }^{2}$ \\ and Kong-Joo Lee ${ }^{1}$ \\ ${ }^{1}$ Graduate School of Pharmaceutical Sciences, College of Pharmacy, Ewha Womans University, Seoul, Korea \\ ${ }^{2}$ Conway Institute, University College Dublin, Dublin, Ireland \\ Correspondence to: Kong-Joo Lee, email: kjl@ewha.ac.kr
}

Keywords: UCH-L 1, Ubiquitination, hydrogen peroxide, NOX4, invasion

Received: December 19,2014 Accepted: March 20,2015 Published: April 15, 2015

This is an open-access article distributed under the terms of the Creative Commons Attribution License, which permits unrestricted use, distribution, and reproduction in any medium, provided the original author and source are credited.

\section{ABSTRACT}

This study explored the role of ubiquitin C-terminal hydrolase-L1 (UCH-L1) in the production of ROS and tumor invasion. UCH-L1 was found to increase cellular ROS levels and promote cell invasion. Silencing UCH-L1, as well as inhibition of $\mathrm{H}_{2} \mathrm{O}_{2}$ generation by catalase or by DPI, a NOX inhibitor, suppressed the migration potential of B16F10 cells, indicating that UCH-L1 promotes cell migration by up-regulating $\mathrm{H}_{2} \mathrm{O}_{2}$ generation. Silencing NOX4, which generates $\mathrm{H}_{2} \mathrm{O}_{2}$, with siRNA eliminated the effect of UCH-L1 on cell migration. On the other hand, NOX4 overexpressed in HeLa cells happens to be ubiquitinated, and NOX4 following deubiquitination by UCH-L1, restored $\mathrm{H}_{2} \mathrm{O}_{2}$-generating activity. These in vitro findings are consistent with the results obtained in vivo with catalase $(-/-)$ C57BL/6J mice. When $\mathrm{H}_{2} \mathrm{O}_{2}$ and UCH-L1 levels were independently varied in these animals, the former by infecting with $\mathrm{H}_{2} \mathrm{O}_{2}$-scavenging adenovirus-catalase, and the latter by overexpressing or silencing UCH-L1, pulmonary metastasis of B16F10 cells overexpressing UCH-L1 increased significantly in catalase (-/-) mice. In contrast, invasion did not increase when UCH-L1 was silenced in the B16F10 cells. These findings indicate that $\mathrm{H}_{2} \mathrm{O}_{2}$ levels regulated by UCH-L1 are necessary for cell invasion to occur and demonstrate that UCH-L1 promotes cell invasion by up-regulating $\mathrm{H}_{2} \mathrm{O}_{2}$ via deubiquitination of NOX4.

\section{INTRODUCTION}

Metastasis is the phenomenon in which tumor cells break away from a primary site, circulate through the bloodstream, infiltrate vascular and lymphatic vessels, and settle and proliferate elsewhere in the body [1-3]. This process involves the interplay of malignant cell- and host-associated factors [4], including the microenvironment of the extravasated cancer cells and factors that promote the survival and growth $[5,6]$ of the tumor cells. These factors are believed to include ROS [710] such as hydrogen peroxide $\left(\mathrm{H}_{2} \mathrm{O}_{2}\right)$, superoxide $\left(\mathrm{O}_{2}\right.$ ), and hydroxyl radical $\left(\mathrm{OH}^{\circ}\right)$, which are up-regulated in the tumor microenvironment. Various studies support the role of ROS in cancer, angiogenesis [11], mitogenesis, and resistance to apoptosis $[12,13]$. Introduction of oncogenes into immortalized cells leads to increases in cellular ROS, and ROS-generating genes such as NADPH oxidases (NOX). NOX have been shown to contribute to tumorigenesis and angiogenesis [14-17]. Of special interest, inhibition of NOX4 suppressed the growth of melanoma cells, indicating that NOX4-generated ROS are required for transformation of melanoma cells [18].

Levels of ubiquitin-C-terminal hydrolase-L1 (UCH-L1), which catalyzes hydrolysis of C-terminal ubiquitin esters and amides, increase in various cancers [19-23], especially during tumor invasion and metastasis $[24,25]$. This raises the question, whether the roles played by ROS and UCH-L1 in tumor-cell invasion and metastasis are interrelated. In this study, we explored this question in vitro in murine metastastic melanoma (B16F10) and HeLa cells, and also in vivo in a catalase 
(-/-) mouse model. We confirmed that $\mathrm{H}_{2} \mathrm{O}_{2}$ regulates tumor invasion and that $\mathrm{UCH}-\mathrm{L} 1$ significantly increases both cell migration and $\mathrm{H}_{2} \mathrm{O}_{2}$ generation. Both processes were attenuated when $\mathrm{H}_{2} \mathrm{O}_{2}$ was removed using Advcatalase, or by treatment with the NOX inhibitor DPI, or by inhibiting ROS generation using NOX4 siRNA. Also, we demonstrated that $\mathrm{UCH}-\mathrm{L} 1$ restores $\mathrm{H}_{2} \mathrm{O}_{2}-$ gernerating activity of NOX4 by deubiquitinating NOX4. These findings suggest that UCH-L1 plays a key role in tumor invasion by modulating the $\mathrm{H}_{2} \mathrm{O}_{2}$ generating $\mathrm{NOX} 4$ activity.

\section{RESULTS}

\section{UCH-L1 affects cellular ROS generation}

In a previous study, we showed that UCH-L1 plays a key role in lung metastasis [25], but we did not explore the underlying mechanism. Since ROS play important roles in tumor progression, and in pro-metastatic signaling pathway $[8,26]$, we investigated whether UCH-L1 is involved in ROS-mediated cell invasion.

First, we generated stable UCH-L1-overexpressingor UCH-L1-knocked down-B16F10 cells and compared their invasiveness using transwell chambers coated with matrigel in vitro. As shown in Figure 1a, B16F10 cells overexpressing UCH-L1 showed increased ability for invasion, while knocking-down UCH-L1 decreased their invasiveness. These results suggest that there is a positive correlation between UCH-L1 expression levels and cell invasion. Next, we examined whether UCH-L1 expression is associated with cellular ROS generation, assessing cellular ROS levels by measuring fluorescence generated by ROS after loading the cells with $\mathrm{CM}-\mathrm{H}_{2} \mathrm{DCFDA}$. B16F10 cells overexpressing UCH-L1 showed increased cellular ROS levels (Figure 1b and 1c), while knocking it down with various siRNA decreased the cellular ROS levels (Figure 1d). These results indicate that UCH-L1 increases cellular ROS generation.

\section{UCH-L1 is involved in $\mathrm{H}_{2} \mathrm{O}_{2}$-mediated cell invasion}

Recent studies reported that $\mathrm{H}_{2} \mathrm{O}_{2}$ might cooperate with TGF- $\beta$ to induce the metastatic phenotype of HCC cells [27]. Induction of the metastatic phenotype is accompanied by increases in steady-state $\mathrm{H}_{2} \mathrm{O}_{2}$ that drives pro-migratory signaling [28].

We examined whether UCH-L1 is involved in $\mathrm{H}_{2} \mathrm{O}_{2}$-mediated cell invasion in vivo, by assessing pulmonary metastasis in catalase (-/-) mice, and in B16F10 cells stably overexpressing UCH-L1, infected with Adv-catalase. Because catalase is a specific $\mathrm{H}_{2} \mathrm{O}_{2}$ scavenging enzyme, catalase (-/-) mice exhibit lower ability to consume extracellular $\mathrm{H}_{2} \mathrm{O}_{2}$ in lung and liver [29]. As shown in Figure 2a, pulmonary metastasis of B16F10 cells overexpressing UCH-L1 is increased in both catalase $(-/-)$ and catalase $(+/+)$ mice relative to that of control cells. This effect is greater in catalase (-/-) mice than in catalase $(+/+)$ mice. Pulmonary metastasis of B16F10 cells overexpressing UCH-L1 was attenuated in mice injected with Adv-catalase-infected B16F10 cells by up to $75 \%$, compared to that in mice injected with Advector-infected B16F10 cells. Additionally, pulmonary metastasis of UCH-L1-knocked-down B16F10 cells was significantly less than that of control cells in both catalase $(-/-)$ and catalase $(+/+)$ mice (Figure $2 \mathrm{~b}$ and $2 \mathrm{c}$ ). These results indicate that the effect of knocking down UCH-L1 on pulmonary metastasis of B16F10 cells is similar to that of infection with Adv-catalase, and that UCH-L1 is involved in $\mathrm{H}_{2} \mathrm{O}_{2}$-mediated cell invasion by altering $\mathrm{H}_{2} \mathrm{O}_{2}$ levels in invasive cells. We also found that metastasis of B16F10 cells to the lungs of catalase (-/-) mice (right upper panel in Figure 2 b) significantly increased compared to that in catalase $(+/+)$ mice (left upper panel in Figure $2 \mathrm{~b})$. This finding indicates that metastasis is higher in catalase (-/-) mice, and that the $\mathrm{H}_{2} \mathrm{O}_{2}$ levels in the host microenvironment are also important for the metastatic process.

\section{Adv-catalase infection attenuates the enhancing effect of UCH-L1 on cell invasion in vitro}

To confirm that UCH-L1 promotes pulmonary metastasis in vivo by altering $\mathrm{H}_{2} \mathrm{O}_{2}$ levels in the invasive cells, we examined whether UCH-L1-induced ROS generation is blocked by Adv-catalase infection in a MOIdependent manner (10-50 MOI) in vitro. As shown in Figure $3 \mathrm{a}, \mathrm{H}_{2} \mathrm{O}_{2}$ in $\mathrm{B} 16 \mathrm{~F} 10$ cells overexpressing UCH-L1 was significantly attenuated when cells were infected with Adv-catalase, but not Adv-vector. The fluorescence intensity (geometric mean (Geo Mean)) of cells infected with Adv-catalase, assessed using FACS, was less than that of cells infected with Adv-vector (Figure 3b).

Moreover, the migration of B16F10 cells overexpressing UCH-L1 was significantly reduced after infection with Adv-catalase in a MOI-dependent manner (Figure 3c). These results demonstrate that UCH-L1 overexpression leads to enhanced $\mathrm{H}_{2} \mathrm{O}_{2}$ generation, and that invasion induced by UCH-L1 is reduced by eliminating $\mathrm{H}_{2} \mathrm{O}_{2}$, suggesting that UCH-L1 plays a role in the regulation of $\mathrm{H}_{2} \mathrm{O}_{2}$ generation.

\section{NOX4 siRNA attenuates UCH-L1-mediated $\mathrm{H}_{2} \mathrm{O}_{2}$ generation and cell invasion}

It has been reported that NOX4 promotes proliferation and metastasis of non-small lung cancer cells [30] and induces epithelial-to-mesenchymal transition and 


\section{a}

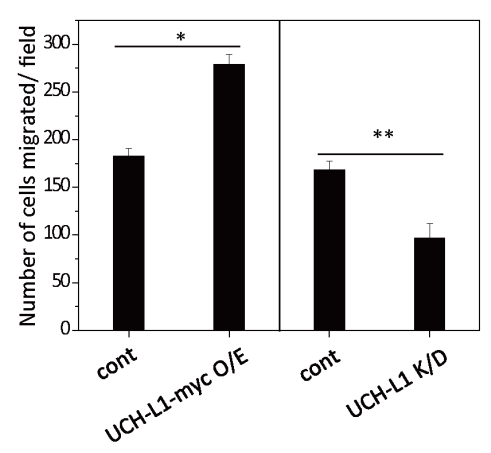

b
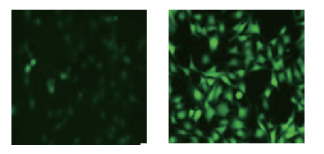

cont

UCH-L1 myc O/E
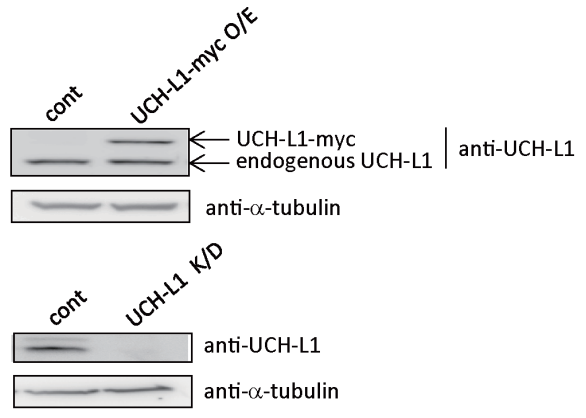

C

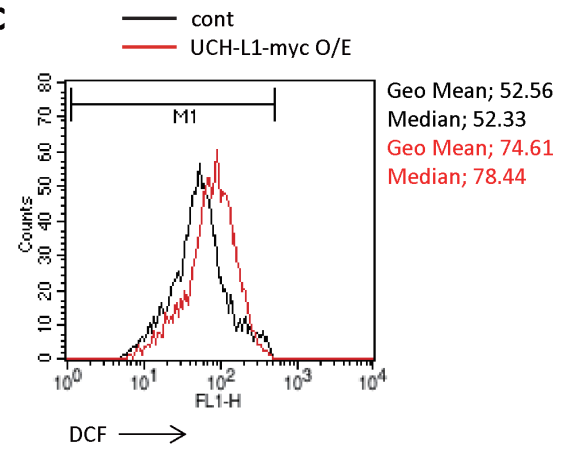

\section{d}

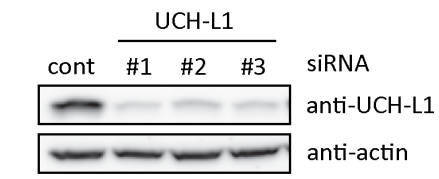

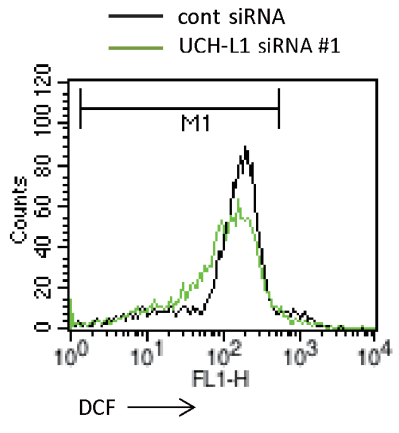

Geo Mean; 119.38

Median; 153.99

Geo Mean; 89.60

Median; 111.40

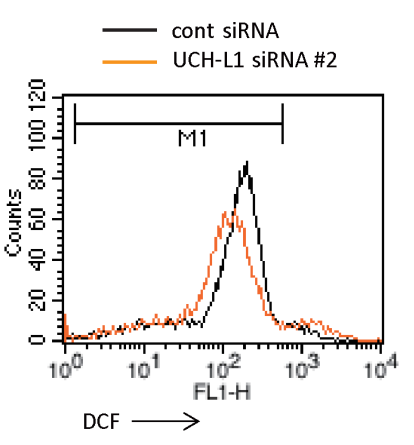

Geo Mean; 119.38 Median; 153.99 Geo Mean; 88.67 Median; 106.50

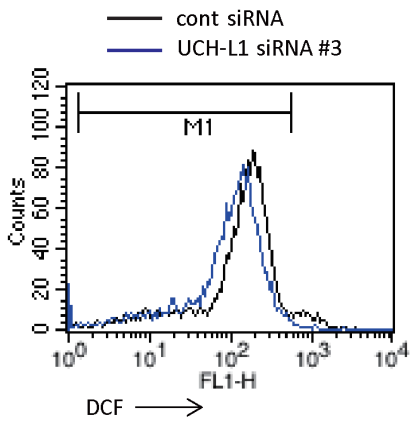

Geo Mean; 119.38

Median; 153.99

Geo Mean; 91.47

Median; 113.42

Figure 1: UCH-L1 enhances cellular ROS generation. a. B16F10 cells expressing UCH-L1 (UCH-L1-myc O/E), UCH-L1 shRNA $(\mathrm{UCH}-\mathrm{L} 1 \mathrm{~K} / \mathrm{D})$ or control vector (cont) were immunoblotted for UCH-L1, using tubulin as control. Cells $\left(1 \times 10^{4}\right)$ were seeded on matrigelcoated inserts in transwell chamber and incubated at $37^{\circ} \mathrm{C}$ for $24 \mathrm{~h}$. Cells migrated through the filter were counted. Data are mean $\pm \mathrm{SD}(n$ $=3)$. $* P<0.05$ for cont $v s$. UCH-L1 O/E, $* * P<0.05$ for cont vs. UCH-L1 K/D. b. Cellular ROS levels were determined by fluorescence microscopy using CM-H $\mathrm{H}_{2}$ DCFDA. c. For flow cytometry, equal numbers of cells were treated with $3 \mu \mathrm{M} \mathrm{CM}-\mathrm{H}_{2} \mathrm{DCFDA}$ in $\mathrm{HBSS}$ at $37^{\circ} \mathrm{C}$ for $15 \mathrm{~min}$ and immediately, the fluorescence intensity was measured. d. B16F10 cells were transfected with UCH-L1 specific siRNAs (\#13 ) for $48 \mathrm{~h}$. Equal numbers of cells were treated with $3 \mu \mathrm{M} \mathrm{CM}-\mathrm{H}_{2}$ DCFDA in HBSS at $37^{\circ} \mathrm{C}$ for 15 min and then the fluorescence intensity was measured by flow cytometry. Geometric mean (Geo Mean) fluorescence intensity and Median value of histogram are calculated by statistical analysis of BD CellQuest software. 


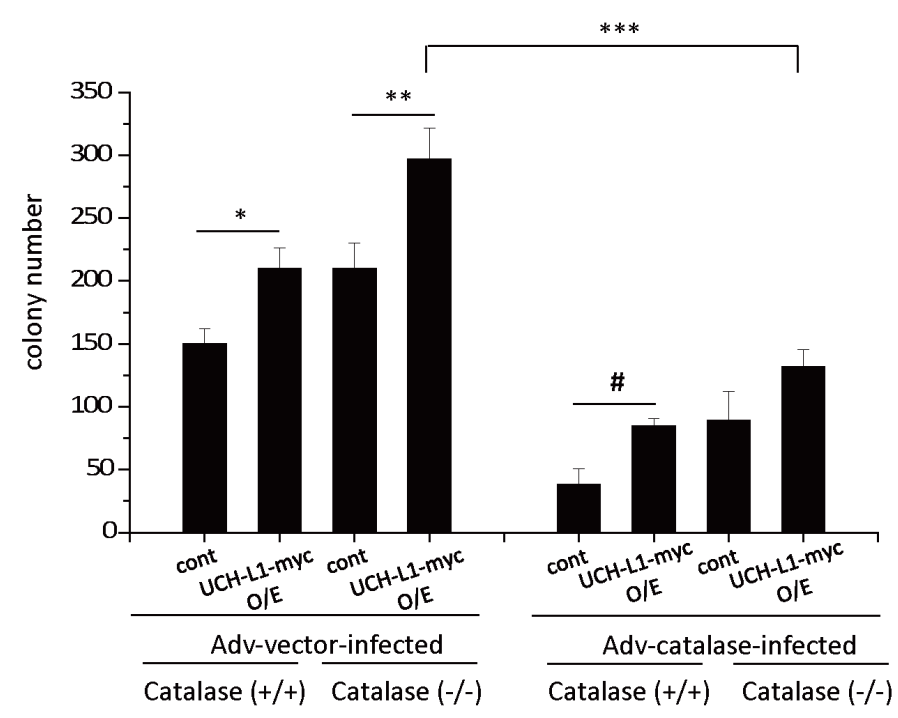

b

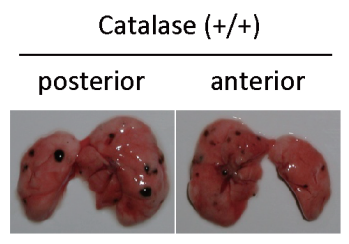

control

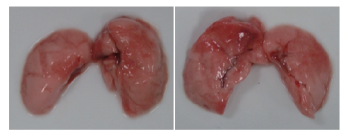

UCH-L1 shRNA

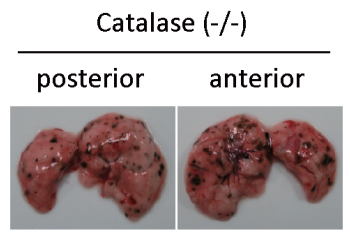

control

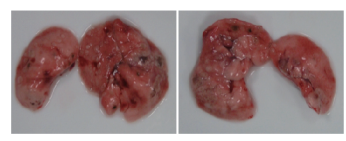

UCH-L1 shRNA
C

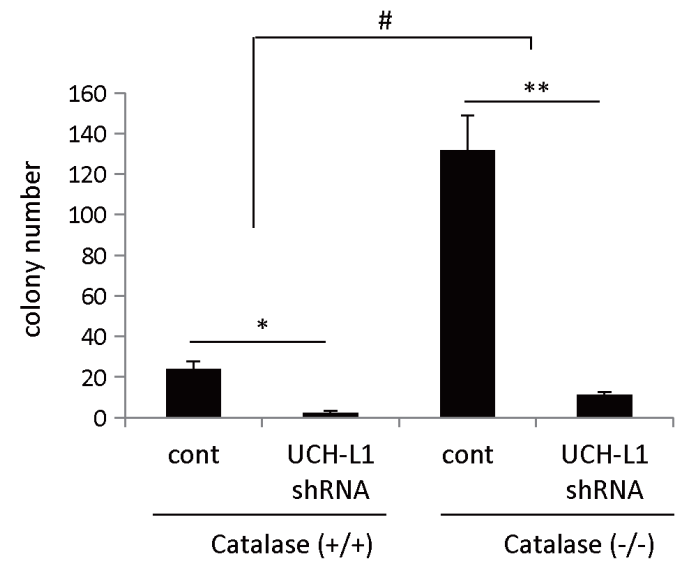

Figure 2: UCH-L1 is involved in $\mathrm{H}_{2} \mathrm{O}_{2}$-mediated pulmonary metastasis in vivo. a. UCH-L1 overexpressing (UCH-L1-myc $\mathrm{O} / \mathrm{E})$ or control (cont) B16F10 cells were infected with Adv-vector (Adv-vector-infected) and Adv-catalase (Adv-catalase-infected) $(1 \times$ $10^{5}$ plaque forming units $\left.(\mathrm{PFU})\right)$. Cells $\left(1.0 \times 10^{6}\right)$ were i.v. injected into tail vein of male C57BL/6 catalase $(+/+)$ mice and catalase $(-/-)$ mice. Two weeks after i.v. injection, the lung was extirpated, and the black spherical B16F10 colonies were counted. Data are mean $\pm \mathrm{SD}(n$ = 7). $* P<0.05$ for catalase $(+/+)$ (Adv-vector-infected cont) $v s$. catalase $(+/+)$ (Adv-vector-infected UCH-L1 O/E), $* * P<0.05$ for catalase $(-/-)$ (Adv-vector-infected cont) vs. Catalase (-/-) (Adv-vector-infected UCH-L1 O/E), ${ }^{\#} P<0.05$ for catalase (+/+) (Adv-catalase-infected cont) $v$ s. catalase $(+/+)(\mathrm{Adv}-$ catalase-infected UCH-L1 O/E), $* * * P<0.05$ for catalase $(-/-)(\mathrm{Adv}-\mathrm{vector}$-infected UCH-L1 O/E) $v s$. catalase $(-/-)(A d v-c a t a l a s e-i n f e c t e d ~ U C H-L 1 \mathrm{O} / \mathrm{E})$. b. In vivo pulmonary metastasis assay by injecting B16F10 cells $\left(1.0 \times 10^{6}\right)$ knocked down UCH-L1 (UCH-L1 shRNA) or control cells intravenously into the tail vein of male C57BL/6 catalase (+/+) mice and catalase (-/-) mice. The images were photographed immediately without fixation after being extirpated. c. The results of pulmonary metastasis were presented in bar graph. Two weeks after i.v. injection, the lung was extirpated, and the black spherical B16F10 colonies were counted. Data are mean $\pm \mathrm{SD}(n=5-7) . * P<0.05$ for catalase $(+/+)$ (cont) $v s$. catalase $(+/+)(\mathrm{UCH}-\mathrm{L} 1$ shRNA), $* * P<0.05$ for catalase (-/-) (cont) $v s$. catalase (-/-) (UCH-L1 shRNA), ${ }^{\#} P<0.05$ for catalase $(+/+)$ mice $v$ s. catalase $(-/-)$ mice. 
a
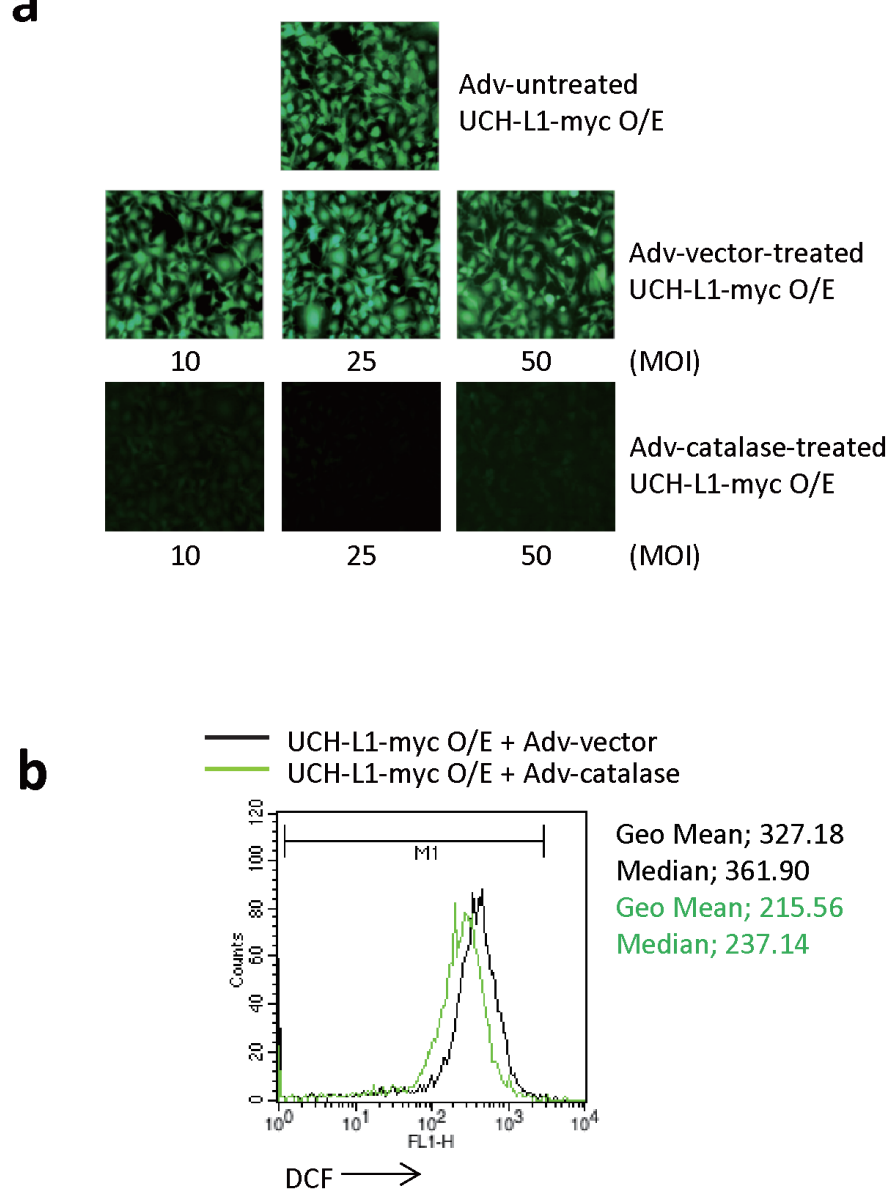

\section{C}
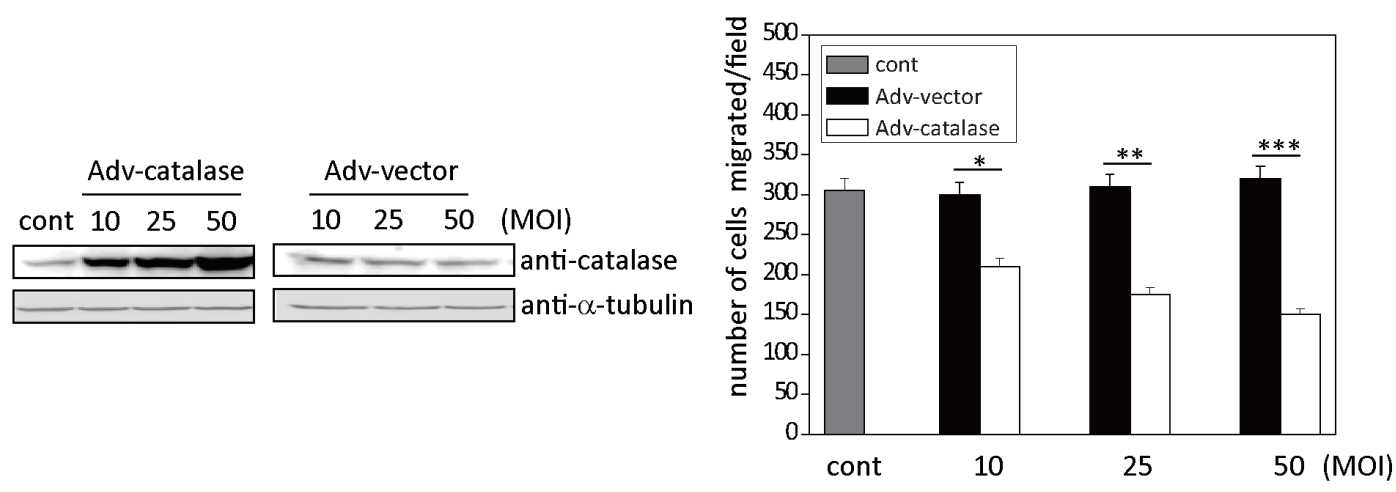

Figure 3: Adv-catalase attenuates the positive effect of UCH-L1 on cell invasion in vitro. a. Cellular ROS levels of UCH-L1overexpressing B16F10 cells infected with Adv-vector (10, 25, 50 MOI) or Adv-catalase (10, 25, 50 MOI) were determined by fluorescence microscopy using CM-H ${ }_{2}$ DCFDA. b. UCH-L1-overexpressing B16F10 cells were treated with Adv-vector or Adv-catalase (25 MOI) and incubated with $3 \mu \mathrm{M}$ of CM- $\mathrm{H}_{2}$ DCFDA in HBSS at $37^{\circ} \mathrm{C}$ for $15 \mathrm{~min}$ and analyzed by flow cytometry. Geometric mean (Geo Mean) fluorescence intensity and Median value of histogram are calculated by statistical analysis of BD CellQuest software. $\mathbf{c}$. After infection with Adv-vector or Adv-catalase, B16F10 cells were immunoblotted for catalase with tubulin as control, and seeded on transwell chambers to determine migration. Data are mean $\pm \mathrm{SD}(n=3) . * P<0.05$ for Adv-vector $v s$. Adv-catalase (10 MOI), ${ }^{* *} P<0.05$ for Adv-vector $v s$. Adv-catalase (25 MOI), ${ }^{* * *} P<0.05$ for Adv-vector $v s$. Adv-catalase (50 MOI). 
migration of breast epithelial cells [31]. Additionally, the ROS released from NOX4 was shown to be $\mathrm{H}_{2} \mathrm{O}_{2}$ [32-35].

To determine whether the likely source of ROS in B16F10 cells overexpressing UCH-L1 is NOX family of NADPH oxidases, we first examined the effect of DPI, a flavoprotein inhibitor of NOX, on ROS generation in these cells. After exposing the cell lines to $20 \mu \mathrm{M}$ of DPI for $30 \mathrm{~min}$, their cellular ROS levels and migratory capacities were measured in vitro. We found that both the generation of ROS (Supplementary Figure 1A) and migration (Supplementary Figure 1B) of B16F10 cells overexpressing UCH-L1 were significantly attenuated by DPI. This suggests that UCH-L1 mediates ROS generation via NOXs in B16F10 cells overexpressing UCH-L1.

Next, to test the possibility that UCH-L1 can modulate $\mathrm{NOX} 4$ causing increased $\mathrm{H}_{2} \mathrm{O}_{2}$ generation, we investigated whether UCH-L1 regulates NOX4-dependent cell migration using NOX4 specific siRNA. As shown in Figure $4 \mathrm{a}$ and $4 \mathrm{~b}$, NOX4-specific siRNA significantly decreased both NOX4 mRNA and protein levels, while overexpression of UCH-L1 did not affect either. Knocking down NOX4 in B16F10 cells significantly reduced both basal and UCH-L1 enhanced invasiveness of cells (Figure $4 \mathrm{c}$ ), suggesting that both inherent and UCH-L1-enhanced invasiveness of B16F10 cells depend on NOX4.

\section{UCH-L1 decreases ubiquitinated NOX4}

Because UCH-L1 hydrolyses ubiquitin C-terminal, and because NOX4 contains Lys (K) residues in the structural regions implicated in NOX4 catalytic activity $[34,36]$, we wondered whether NOX4 activity is regulated by post-translational modifications such as ubiquitination or deubiquitination.

First, we examined whether $\mathrm{UCH}-\mathrm{L} 1$ regulates the expression of NOX4 mRNA or NOX4 protein [32]. As shown in Supplementary Figure 2A, no differences were found in NOX4 mRNA expression between $\mathrm{UCH}$ L1-overexpressing and UCH-L1 knocked down B16F10 cells. The amount of NOX4 protein expressed in B16F10 cells overexpressing UCH-L1 was also not significantly different from that in B16F10 cells in which UCH-L1 was knocked down (Supplementary Figure 2B). Additionally, we examined whether UCH-L1 regulates NOX4 degradation by treating the cells with cycloheximide, an inhibitor of protein synthesis. No difference was observed in endogenous NOX4 in UCH-L1-overexpressing and control cells (Supplementary Figure 2C). These results suggest that UCH-L1 does not influence the expression of NOX4.

Next, we examined whether NOX4 can be ubiquitinated and deubiquitinated by UCH-L1 in HeLa cells, which lack endogenous UCH-L1 [37], and in which NOX4 is barely detectable by western blotting with antiNOX4 antibody. HeLa cells transfected with V5-NOX4 expression vector with or without HA-Ub expression vector were immunoprecipitated with V5 antibody and the precipitate was analyzed by western blotting using anti-V5 and anti-HA antibodies. As shown in Figure 5a, ubiquitinated NOX4 was detected only in cells cotransfected with both V5-NOX4 and HA-Ub expression vectors. To further confirm that NOX4 is ubiquitinated (shown in Figure 5A right lower panel), NOX4 was immunoprecipitated using anti-V5 antibody from bigger batch of samples in Figure 5a, the immune complexes separated on SDS-PAGE and detected with silverstaining (Figure 5b). Newly appearing protein bands 1-4 (red boxes) were identified by peptide sequencing using nanoUPLC-ESI-q-TOF tandem MS after digestion of the proteins in the bands with trypsin. Lane 2 corresponding to only HA-Ub served as control for V5-NOX expression in lanes 3 and 4. Proteins and peptides identified in this experiment are listed in Table 1, after excluding the nonspecific proteins identified in control lane 2 from the list of proteins in lanes 3 and 4. As expected, NOX4, ubiquitin, and Lys-48 linkage ubiquitin chain were verified at bands 3 and 4 in the lane 4.

We investigated whether ubiquitinated NOX4 is a target of UCH-L1, a deubiquitinating enzyme. Figure $5 \mathrm{C}$ shows that ubiquitination of NOX4 was markedly decreased in HeLa cells when UCH-L1-myc expression vector was co-transfected with V5-NOX4 and HA-Ub expression vectors. We further investigated whether endogenous NOX4 is also deubiquitinated by UCH-L1 in B16F10 cells. As shown in Supplementary Figure 3, UCH-L1 siRNA increases the level of ubiquitination of endogenous NOX4 in B16F10 cells. However, when the cells were treated with N-ethylmaleimide (NEM), an irreversible inhibitor of UCH-L1, ubiquitination of NOX4 increased (Figure 5c right lower panel). This was confirmed with UCH-L1 inactive mutant, C90S (Supplementary Figure 4). Immunoprecipitation studies confirmed that UCH-L1 deubiquitinates NOX4, suggesting that UCH-L1 might be involved in $\mathrm{H}_{2} \mathrm{O}_{2}-$ mediated cell invasion by regulating the NOX4 activity through deubiquitination.

\section{UCH-L1 restores $\mathrm{H}_{2} \mathrm{O}_{2}$-generating activity of NOX4 by deubiquitinating NOX4}

To determine whether ubiquitination of NOX4 affects its $\mathrm{H}_{2} \mathrm{O}_{2}$-generating activity, we measured $\mathrm{H}_{2} \mathrm{O}_{2}$ generated from HeLa cells co-transfected with both V5NOX4 and HA-Ub expression vectors using an Amplex Red-based fluorometric assay. As shown in Figure 6A, $\mathrm{H}_{2} \mathrm{O}_{2}$ release increased in a dose-dependent manner by expressing V5-NOX4, but significantly decreased when cells were co-transfected with V5-NOX4 and HA-Ub, indicating that $\mathrm{H}_{2} \mathrm{O}_{2}$-generating activity of NOX4 is in part negatively modulated by ubiquitination. In this 
a

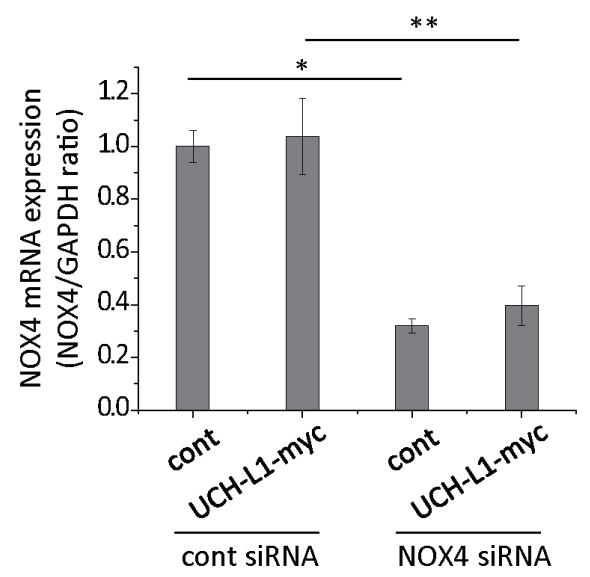

b
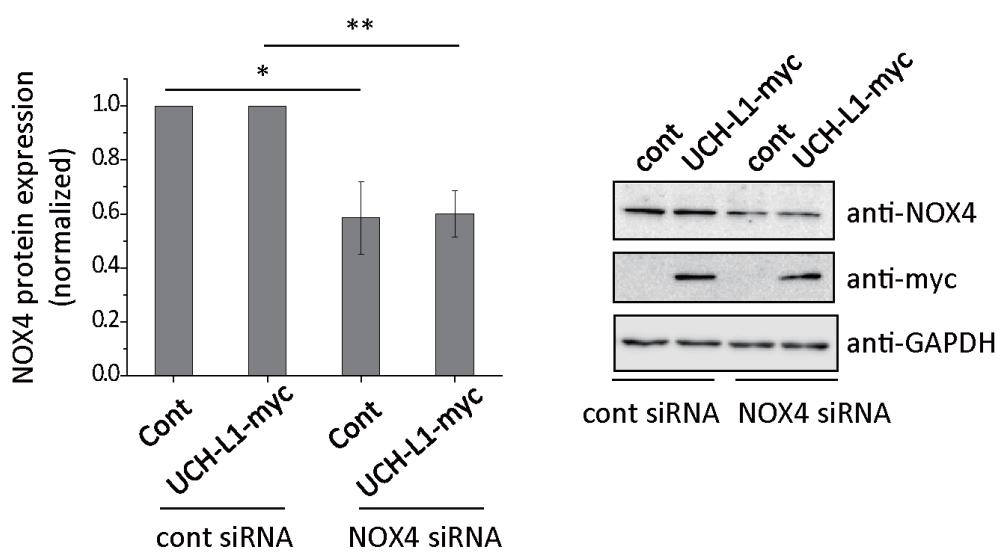

cont SIRNA NOX4 siRNA

C
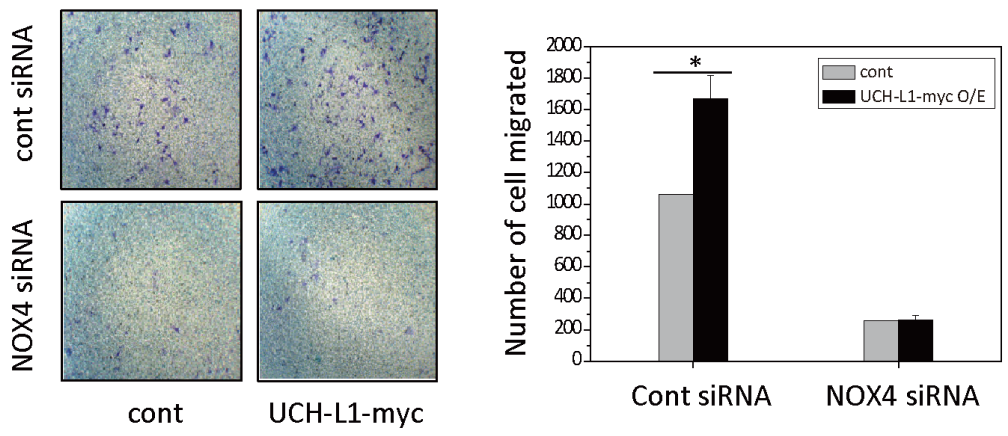

Figure 4: NOX4 siRNA attenuates UCH-L1-mediated $\mathrm{H}_{2} \mathrm{O}_{2}$ generation and cell invasion. a. B16F10 cells were transfected with NOX4 siRNA, followed by analysis of NOX4 mRNA expression by quantitative real-time RT-PCR. The quantity of NOX4 mRNA was normalized to the quantity of a house keeping gene, GAPDH. Data are mean $\pm \mathrm{SD}(n=3)$. ${ }^{*} P<0.05$ for cont (cont siRNA) vs. cont (NOX4 siRNA), ${ }^{* *} P<0.05$ for UCH-L1 O/E (cont siRNA) $v s$. UCH-L1 O/E (NOX4 siRNA). b. NOX4 protein expression was determined using western blotting with anti-NOX4 antibody. Data are mean $\pm \mathrm{SD}(n=3)$. $* P<0.05$ for cont (cont siRNA) vs. cont (NOX4 siRNA), $* * P<0.05$ for UCH-L1 O/E (cont siRNA) $v s$. UCH-L1 O/E (NOX4 siRNA). c. B16F10 cells were transfected with NOX4 siRNA, seeded on transwell chambers and incubated at $37^{\circ} \mathrm{C}$ for $24 \mathrm{~h}$. The invading cells were counted. Data are mean $\pm \mathrm{SD}(n=3)$. ${ }^{*} P<0.05$ for cont (cont siRNA) vs. UCH-L1 O/E (cont siRNA). 
a

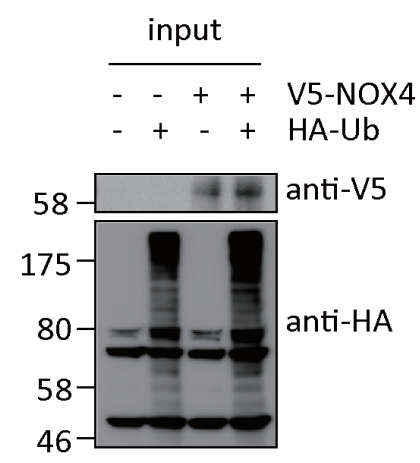

IP with V5
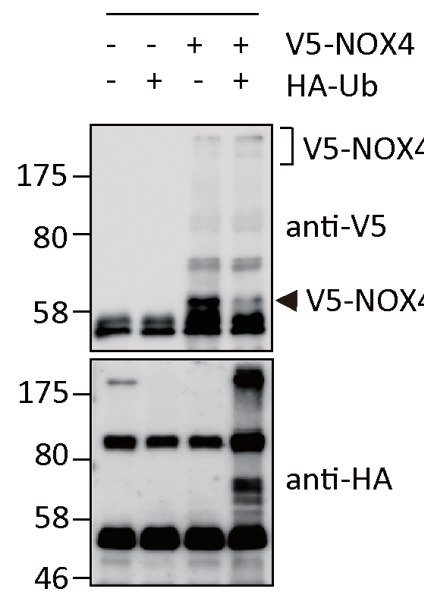

b

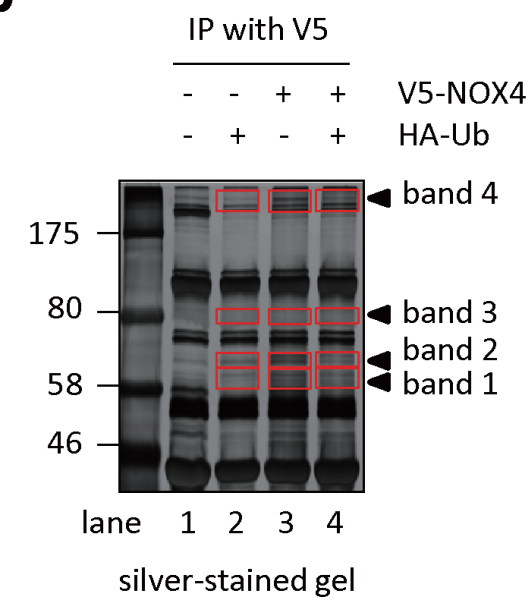

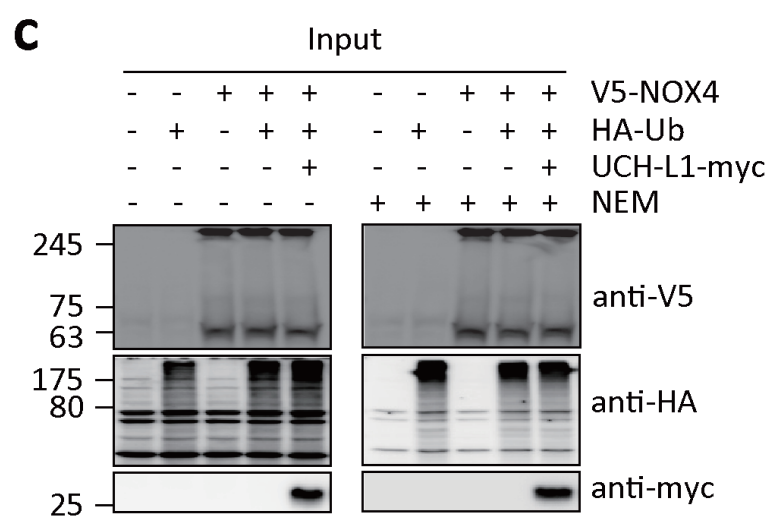

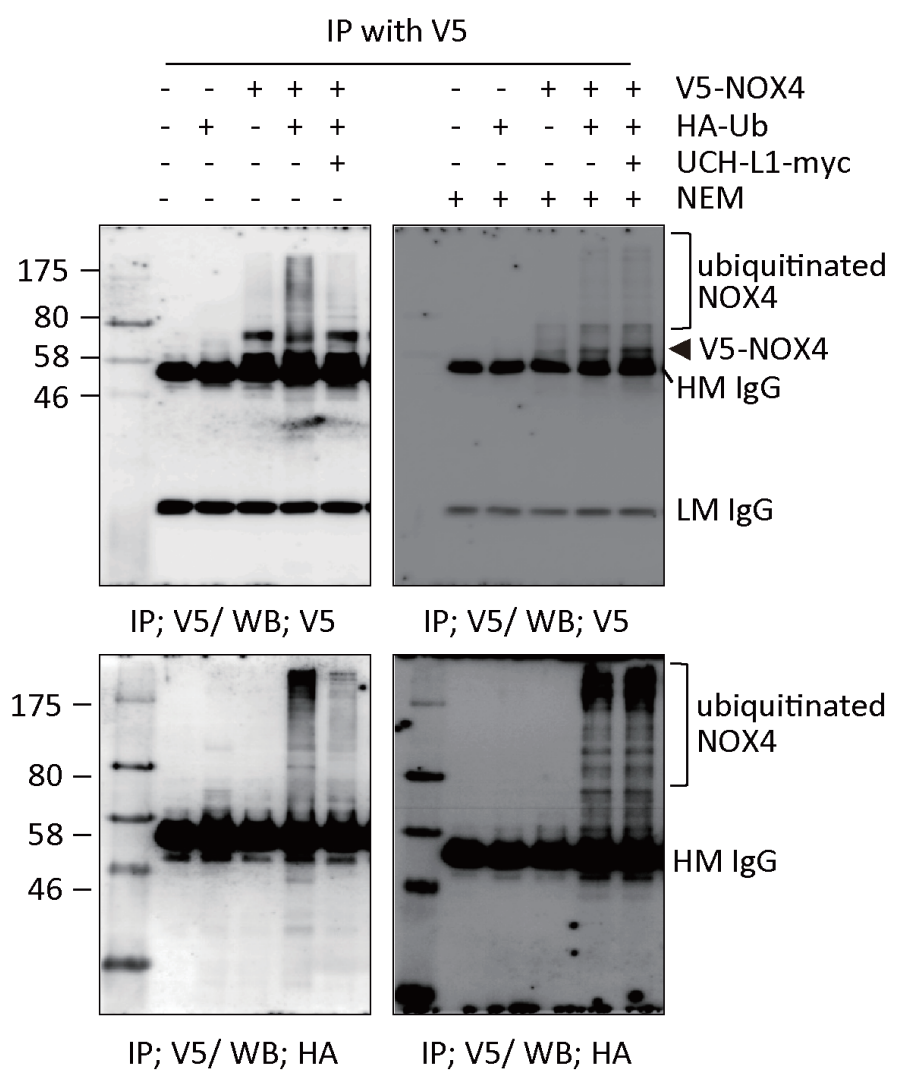

Figure 5: UCH-L1 deubiquitinates NOX4. a. HeLa cells were transfected with V5-NOX4 and/or HA-tagged ubiquitin (HA-Ub) and control expression vectors. Levels of ubiquitination of NOX4 were determined by western blotting of immunoprecipitates with antiHA antibody, while NOX4 expression was monitored with anti-V5 antibody. b. For mass spectrometry analysis, immunoprecipitates were separated on 10\% SDS-PAGE gel, silver-stained, and then analyzed by nanoUPLC-ESI-Q-TOF MS as described in "Methods". Red boxes indicate the analyzed bands in each lane as shown in Table 1. c. HeLa cells were transfected with V5-NOX4, HA-Ub or UCH-L1-myc expression vectors as indicated. Cells were lysed in IP buffer without or with $10 \mathrm{mM}$ of NEM to inhibit UCH-L1 and then immunoprecipitated with anti-V5 antibody. Levels of ubiquitinated NOX4 and total protein levels of V5-NOX4, HA-Ub, and UCH-L1-myc were determined by western blotting. 
Table 1: Proteins identified in immune complex of NOX4 in Figure $5 b$ by nanoUPLC-ESI-q-TOF tandem mass spectrometry.

\begin{tabular}{|c|c|c|c|c|c|c|c|c|c|c|}
\hline Iane & transfection & Band no. & Protein & Accession no. & Observed ms (CS) & Caculated ms & Delta M & Mascot score & peptide matched & Modification \\
\hline \multirow{4}{*}{2} & \multirow{4}{*}{$\mathrm{HA}-\mathrm{Ub}$} & Band 1 & \multicolumn{8}{|c|}{ N.D. } \\
\hline & & Band 2 & \multicolumn{8}{|c|}{ N.D. } \\
\hline & & Band 3 & \multicolumn{8}{|c|}{ N.D. } \\
\hline & & Band 4 & \multicolumn{8}{|c|}{ N.D. } \\
\hline \multirow{5}{*}{3} & \multirow{5}{*}{ V5-NOX4 } & Rand 1 & \multirow{2}{*}{ Nox 4} & \multirow{2}{*}{ Q7Z7G3 } & $1128.0526(2+)$ & 2254.1845 & -0.0938 & 24 & DLLLPPSSQDSEI LPFIQSR & \\
\hline & & Bana 1 & & & $474.7578(2+)$ & 947.5328 & -0.0317 & 18 & LLFDEIAK & \\
\hline & & Band 2 & \multicolumn{8}{|c|}{ N.D. } \\
\hline & & Band 3 & Ubiquitin & P62988 & $534.3415(2+)$ & 1066.6135 & 0.055 & 51 & ESTLHLVLR & \\
\hline & & Band 4 & \multicolumn{8}{|c|}{ N.D. } \\
\hline \multirow{12}{*}{4} & \multirow{12}{*}{$\begin{array}{c}\text { HA-Ub } \\
+ \\
\text { V5-NOX4 }\end{array}$} & \multirow{2}{*}{ Band 1} & \multirow{2}{*}{ Nox 4} & \multirow{2}{*}{ Q7Z7G3 } & $1128.0204(2+)$ & 2254.1845 & -0.1582 & 26 & DLLLPPSSQDSEILPFIQSR & \\
\hline & & & & & $474.7406(2+)$ & 947.5328 & -0.0661 & 15 & LLFDEIAK & \\
\hline & & Band 2 & \multicolumn{8}{|c|}{ N.D. } \\
\hline & & \multirow{5}{*}{ Band 3} & \multirow{2}{*}{ Nox 4} & \multirow{2}{*}{ Q7Z7G3 } & $488.2494(2+)$ & 974.4821 & 0.0021 & 19 & IVGDWTER & \\
\hline & & & & & $1128.058(2+)$ & 2254.1845 & -0.083 & 22 & DLLLPPSSQDSEI LPFIQSR & \\
\hline & & & \multirow{3}{*}{ Ubiquitin } & \multirow{3}{*}{ P62988 } & $487.5997(3+)$ & 1459.7783 & -0.001 & 48 & LIFAGKQLEDGR & GlyGly (K48) \\
\hline & & & & & $541.2819(2+)$ & 1080.5451 & 0.0041 & 37 & TLSDYNIQK & \\
\hline & & & & & $534.3121(2+)$ & 1066.6135 & -0.0038 & 12 & ESTLHLVLR & \\
\hline & & \multirow{4}{*}{ Band 4} & \multirow{2}{*}{ Nox 4} & \multirow{2}{*}{ Q7Z7G3 } & $474.7249(2+)$ & 947.5328 & -0.0975 & 42 & LLFDEIAK & \\
\hline & & & & & $705.3078(2+)$ & 1408.735 & -0.134 & 32 & LLFDEIAKYNR & Formyl (K495) \\
\hline & & & \multirow{2}{*}{ Ubiquitin } & \multirow{2}{*}{ P62988 } & $487.5531(3+)$ & 1459.7783 & -0.1408 & 22 & LIFAGKQLEDGR & GlyGly (K48) \\
\hline & & & & & $534.2647(2+)$ & 1066.6135 & -0.0986 & 54 & ESTLHLVLR & \\
\hline & & \multicolumn{8}{|c|}{ N.D : not detected; CS : charge state; Observed ms : observed mass; Caculated ms } & \\
\hline & & GlyGly (K\#) & ubiquitinati & at Lysine \# of $i$ & lentified peptide & & & & & \\
\hline
\end{tabular}

experiment, cells treated with DPI were used as a negative control.

As shown in Figure 6b, the $\mathrm{H}_{2} \mathrm{O}_{2}$-generating activity of NOX4 decreased in cells transfected with both V5NOX4 and HA-Ub, compared to cells transfected with V5NOX4 alone. However, NOX4 activity was significantly restored when these cells were co-transfected with UCHL1-myc. Cells treated with DPI and $\mathrm{H}_{2} \mathrm{O}_{2}$ in the assay buffer were used respectively as negative and positive controls. Because endogenous NOX4 protein levels in HeLa cells are not high enough for detection by western blotting, we could not detect the positive effect of UCH-L1 on $\mathrm{H}_{2} \mathrm{O}_{2}$-generating activity of NOX4 when HeLa cells were transfected with UCH-L1-myc vector alone (Figure $6 b)$. These results suggest that UCH-L1 restores $\mathrm{H}_{2} \mathrm{O}_{2}$ generating activity of NOX4 through deubiquitination.

We also found that UCH-L1 is colocalized close enough to endogenous NOX4 in B16F10 cells to be deubiquitinated. Co-localization of UCH-L1 and NOX4 was found at the leading edge of plasma membrane in B16F10 cells, using western blot analysis (Figure 7a), and immunocytochemical-staining (Figure 7b). To confirm the cross contamination of membrane fractions in Figure $7 \mathrm{a}$, anti-Flotillin, anti-Lamin B, and anti-Prx6 antibodies were used as reagents for detection of membrane, nucleus, and cytosolic fraction, respectively.

\section{$\mathrm{H}_{2} \mathrm{O}_{2}$ induced in UCH-L1 via NOX4, activates Akt through EGF-induced signal transduction}

To understand how UCH-L1-mediated $\mathrm{H}_{2} \mathrm{O}_{2}$ regulates cell invasion, we examined the kinetics of activation of various kinases including Akt and MAPKs. The Akt and MAPK family can be activated downstream of growth factor receptor kinases [25, 38, 39]. HeLa cells overexpressing UCH-L1 were transiently transfected with empty vector or V5-NOX4 vector, and exposed to EGF (20 ng/mL) for various durations. The observed activation kinetics of Akt, ERK, and p38 are shown in Figure 7c. Activation of Akt in HeLa cells overexpressing UCH-L1 was significantly higher in cells transiently transfected with V5-NOX4, compared to that in cells transfected with vector. No differences were detected in activation of ERK and $\mathrm{p} 38$. These results confirm that the activation of Akt is regulated by UCH-L1- induced $\mathrm{H}_{2} \mathrm{O}_{2}$ through NOX4 in HeLa cells.

\section{DISCUSSION}

In the present study, we have shown that UCH-L1 deubiquitinates $\mathrm{NOX} 4$, thereby up-regulating its ability to generate $\mathrm{H}_{2} \mathrm{O}_{2}$ and promoting the invasive potential of $\mathrm{B} 16 \mathrm{~F} 10$ cells both in vitro and in vivo. We further show that pulmonary metastasis is down-regulated in catalase (-/-) mice injected with B16F10 cells in which UCH-L1 is knocked down with specific shRNA (Figure $2 \mathrm{~b}$ and 2c). We conclude that UCH-L1 is involved in the NOX4- 

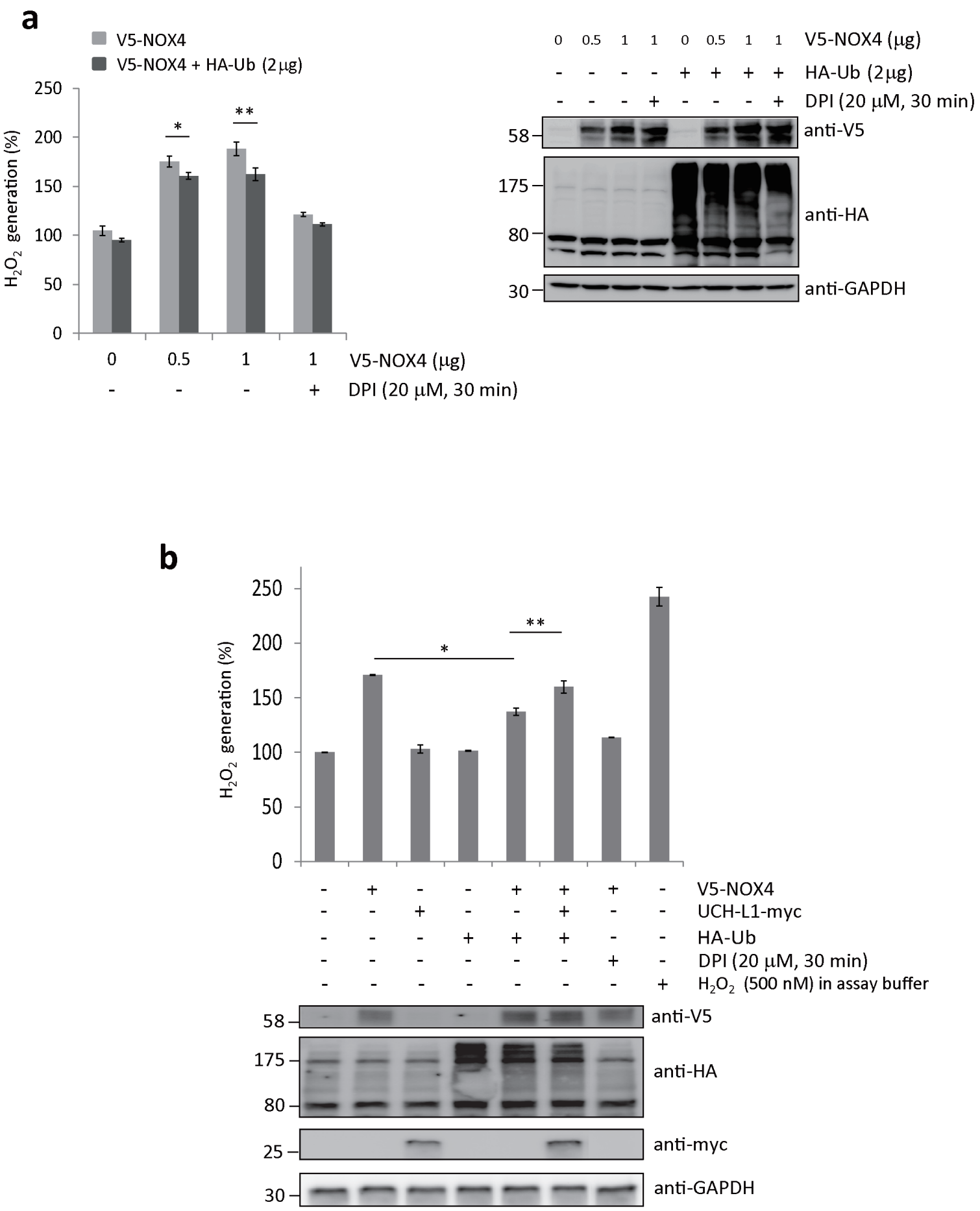

Figure 6: UCH-L1 restores $\mathrm{H}_{2} \mathrm{O}_{2}$-generating activity of NOX4 by deubiquitinating NOX4. A. HeLa cells were transfected with V5-NOX4 expression vector $(0,0.5$, and $1.0 \mu \mathrm{g})$ in a dose-dependent manner with or without $2 \mu \mathrm{g}$ of $\mathrm{HA}-\mathrm{Ub}$ expression vector. $\mathrm{H}_{2} \mathrm{O}_{2}$ release was measured using Amplex ${ }^{\circledR}$ Red. Cells treated with DPI ( $\left.20 \mu \mathrm{M}, 30 \mathrm{~min}\right)$ were used as a negative control. Levels of ubiquitinated NOX4 and total protein levels of HA-Ub and GAPDH were determined by western blotting. Data are mean \pm SD $(n=3)$. $* P<0.05$ for V5-NOX4 $(0.5 \mu \mathrm{g}) v s$. V5-NOX4 $(0.5 \mu \mathrm{g})+\mathrm{HA}-\mathrm{Ub},{ }^{*} * \mathrm{P}<0.05$ for V5-NOX4 $(1 \mu \mathrm{g}) v s$. V5-NOX4 $(1 \mu \mathrm{g})+\mathrm{HA}-\mathrm{Ub}$. B. $\mathrm{H}_{2} \mathrm{O}_{2}$ release was measured using Amplex ${ }^{\circledR}$ Red. Total protein levels of V5-NOX4, HA-Ub, UCH-L1-myc, and GAPDH were determined by western blotting. Cells treated with $20 \mu \mathrm{M}$ of DPI for $30 \mathrm{~min}$ were used as a negative control. $500 \mathrm{nM}$ of $\mathrm{H}_{2} \mathrm{O}_{2}$ in assay buffer was used as a positive control. Data are mean $\pm \mathrm{SD}(n=3)$. ${ }^{*} P<0.05$ for cells transfected only with V5-NOX4 vs. cells transfected with both V5-NOX4 and HA-Ub, ${ }^{* *} P<0.05$ for cells transfected with both V5-NOX4 and HA-Ub vs. cells transfected with V5-NOX4, HA-Ub, and UCH-L1-myc. 
a

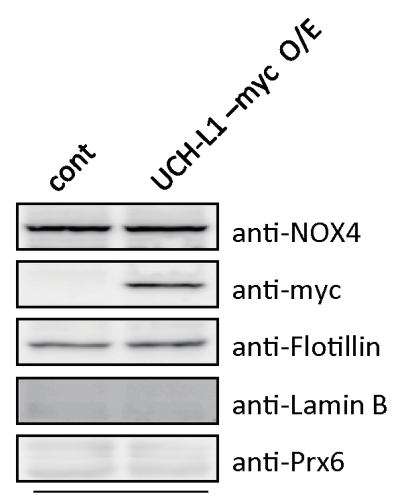

membrane fraction b
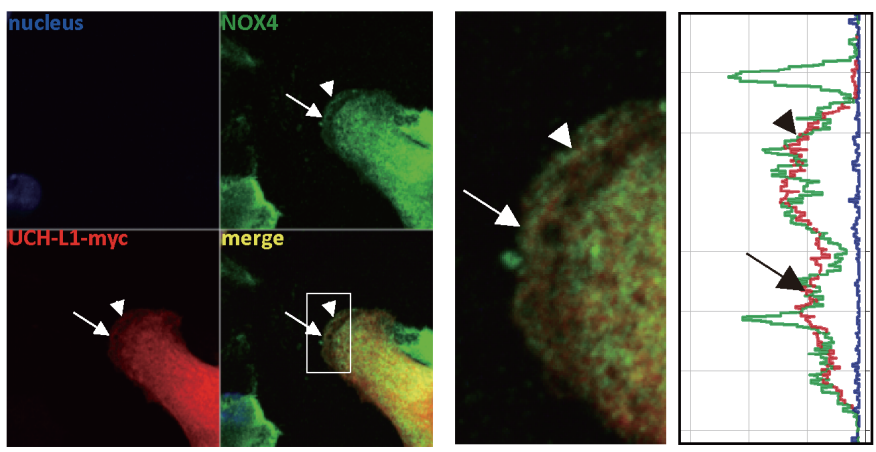

\section{C}

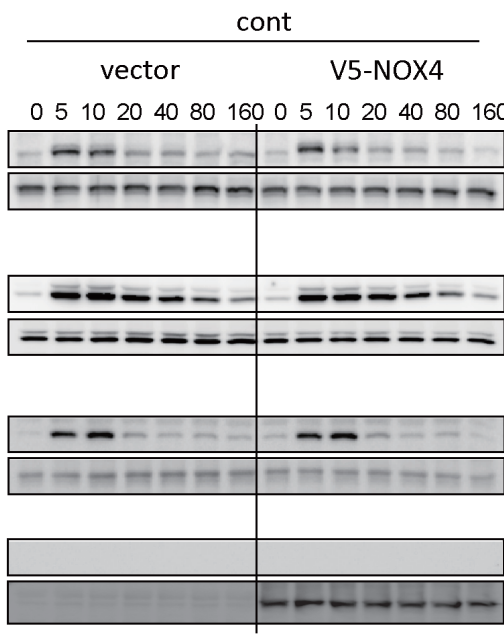

$\frac{\text { UCH-L1-myc O/E }}{\text { vector }}$ V5-NOX4
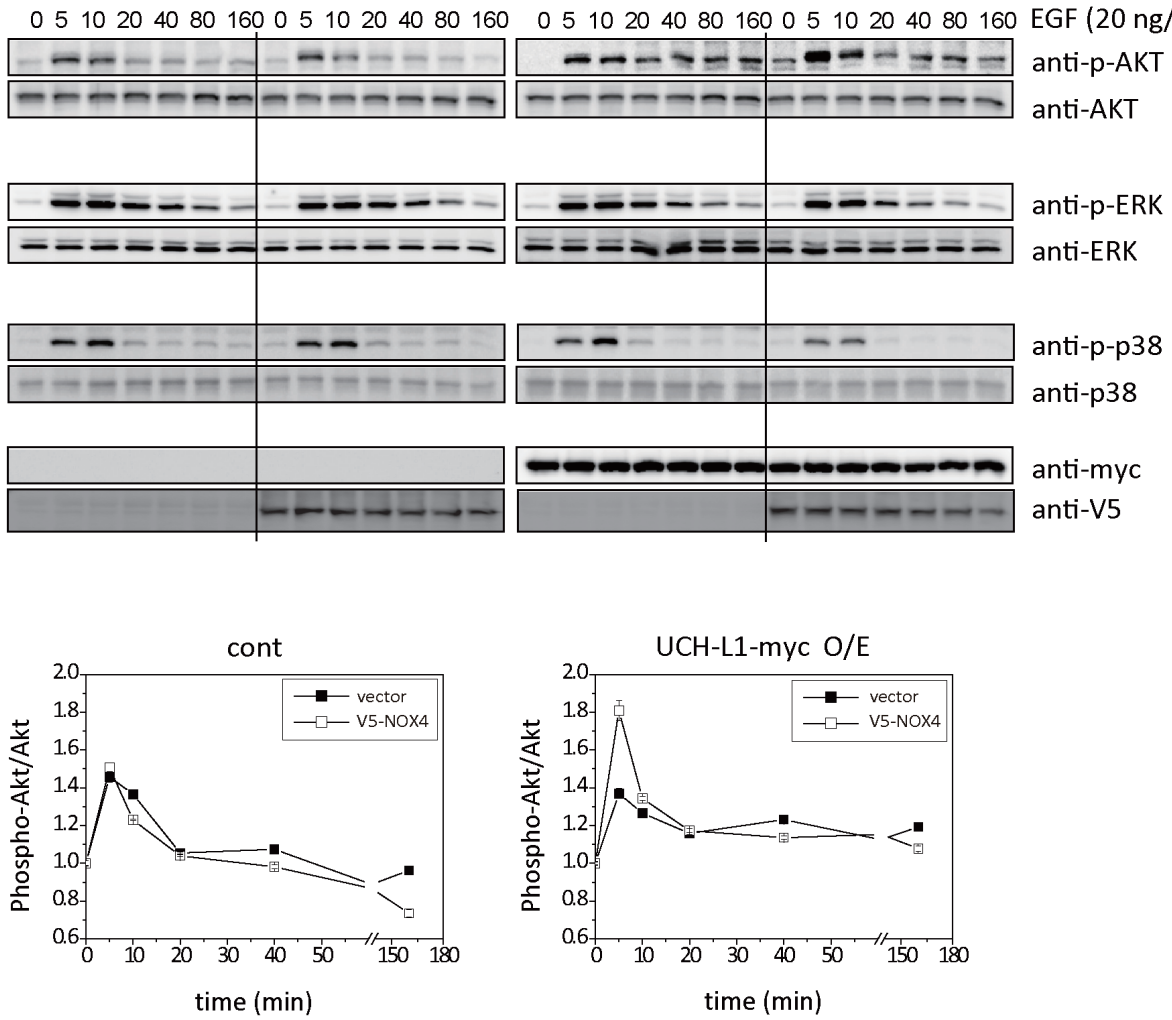

Figure 7: UCH-L1 co-localizes with NOX4 at leading edge of plasma membrane; and $\mathrm{H}_{2} \mathrm{O}_{2}$ induced by UCH-L1 via NOX4, causes Akt activation. A. Immunoblotting of B16F10 cells after cell fractionation using anti-NOX4 and myc (for UCH-L1) antibodies. Anti-flotillin, anti-laminB, and anti-Prx6 antibodies respectively were used as fractionation markers; flotillin for membrane fraction, laminB for nucleus fraction, and Prx6 for cytosolic fraction. B. Localization of UCH-L1 and NOX4 in B16F10 cells was evaluated by fluorescence confocal microscope. White box was magnified to right panel with fluorescence intensity profiles. Arrow and arrow head indicate area of UCH-L1 and NOX4 co-localization in the merge image. C. HeLa cells overexpressing UCH-L1 were transiently transfected with V5-NOX4 expression vector and then starved for $6 \mathrm{~h}$. Cells were then treated with EGF $(20 \mathrm{ng} / \mathrm{mL})$ for various times $(0,5,10,20$, $40,80$, and $160 \mathrm{~min})$. At the indicated time points, EGF-treated cells were lysed and analyzed by western blotting using phospho-ERK (P-ERK), phospho-p38 (P-p38), and phospho-Akt (P-Akt) antibodies. Quantitative analysis was done with multi-gauge software (LAS 3000). Data are mean $\pm \mathrm{SD}(n=3)$. 
mediated $\mathrm{H}_{2} \mathrm{O}_{2}$ generation. A previous study [40] on the role of $\mathrm{UCH}-\mathrm{L} 1$ in tumor metastasis focused only on UCH-L1 expression levels in various tumors including neuroblastoma, pancreatic cancer, but not the levels of $\mathrm{H}_{2} \mathrm{O}_{2}$ induced by UCH-L1. This study is therefore the first to demonstrate the involvement of UCH-L1 in $\mathrm{H}_{2} \mathrm{O}_{2}$ mediated tumor metastasis.

ROS such as $\mathrm{H}_{2} \mathrm{O}_{2}$, superoxide $\left(\mathrm{O}_{2} \cdot{ }^{-}\right)$and hydroxyl radical $(\mathrm{OH} \cdot)$, have been shown to be up-regulated in the tumor microenvironment and trigger cell adhesion, cell migration and invasion [41]. NOX4 has been detected in focal adhesions [42], and on the plasma membrane [43]. Recently, it has been reported that NOX4 promotes nonsmall cell lung cancer cell proliferation and metastasis through positive feedback regulation of PI3K/Akt signaling [30] and is involved in TGF-beta and SMAD3driven induction of the epithelial-to-mesenchymal transition and migration of breast epithelial cells [31]. It has also been reported that NOX4-generated ROS are required for promoting hypoxia-induced invasive potential of U87 cells, and that ROS are potential targets for inhibiting tumor cell invasion and infiltration in glioblastoma [44]. A recent report demonstrated that invasiveness of lung carcinoma $\mathrm{H} 460$ cells is regulated by $\operatorname{ROS}$ [41], and that $\mathrm{OH}^{*}$ promotes the regulation of cancer cell migration. While this report identified $\mathrm{OH}$ - as a positive modulator of lung carcinoma $\mathrm{H} 460$ cell migration, the present study shows that UCH-L1 induces $\mathrm{H}_{2} \mathrm{O}_{2}$ generation by modulating NOX4 activity and that $\mathrm{H}_{2} \mathrm{O}_{2}$ plays an important role in the invasion of B16F10 cells.

A recent study demonstrated that NOX4 is negatively regulated by hydrogen peroxide inducible clone-5 (Hic-5) protein [45], and also that NOX4 protein expression is suppressed by Hic-5 via Cbl-c and HSP27mediated ubiquitination and proteasomal degradation. Our quantitative real time RT-PCR analysis revealed that UCH-L1 does not affect the levels of NOX4 mRNA or protein expression. Also, we showed that ubiquitination down-regulated the catalytic activity of NOX4, while deubiquitination by UCH-L1 increased this activity. These findings point to UCH-L1 as yet another regulator of NOX4 activity. Further studies are required to understand the NOX4 deubiquitination mechanism by UCH-L1, because little is known of UCH-L1 action mechanism except for the demonstrated hydrolase action on ubiquitinC-terminal adducts amides and esters [46].

Signal transduction conducted by the microenvironment around the primary tumor may trigger tumor metastasis, especially at the migration stage. Sustained mitogen activated protein kinase (MAPK)signaling involved in uncontrolled tumor cell migration, depends on crosstalks among integrin, receptor tyrosine kinase (RTK) and protein kinase $\mathrm{C}(\mathrm{PKC})$ [39]. $\mathrm{H}_{2} \mathrm{O}_{2}$ has been shown to contribute to the MnSOD-promoted invasion in glioma cells through activation of Akt and ERK [47]. Here we have shown that UCH-L1-mediated $\mathrm{H}_{2} \mathrm{O}_{2}$ generation via NOX4, influences the activation of Akt in HeLa cells overexpressing UCH-L1, indicating that such $\mathrm{H}_{2} \mathrm{O}_{2}$ generation increases migration of $\mathrm{B} 16 \mathrm{~F} 10$ cells by modulating Akt. This is consistent with our previous finding in $\mathrm{H} 157$ cells that $\mathrm{UCH}-\mathrm{L} 1$ increases cell migration by modulating Akt activation [25].

In studies on pulmonary metastasis of $\mathrm{B} 16 \mathrm{~F} 10$ cells in catalase (-/-) mice, we found evidence that $\mathrm{H}_{2} \mathrm{O}_{2}$ plays an important role in metastasis, that UCH-L1-induces $\mathrm{H}_{2} \mathrm{O}_{2}$ and that increased cellular $\mathrm{H}_{2} \mathrm{O}_{2}$ levels are critical for up-regulation of pulmonary metastasis. This study is also the first to establish $\mathrm{H}_{2} \mathrm{O}_{2}$ as an essential factor for this metastatic process.

In summary, we demonstrated that UCH-L1 promotes $\mathrm{H}_{2} \mathrm{O}_{2}$ generation by up-regulating $\mathrm{NOX} 4$ activity through deubiquitination, and that $\mathrm{H}_{2} \mathrm{O}_{2}$, so produced, plays an important role in cell invasion in vitro by regulating the upstream kinase Akt (Figure 8). Employing

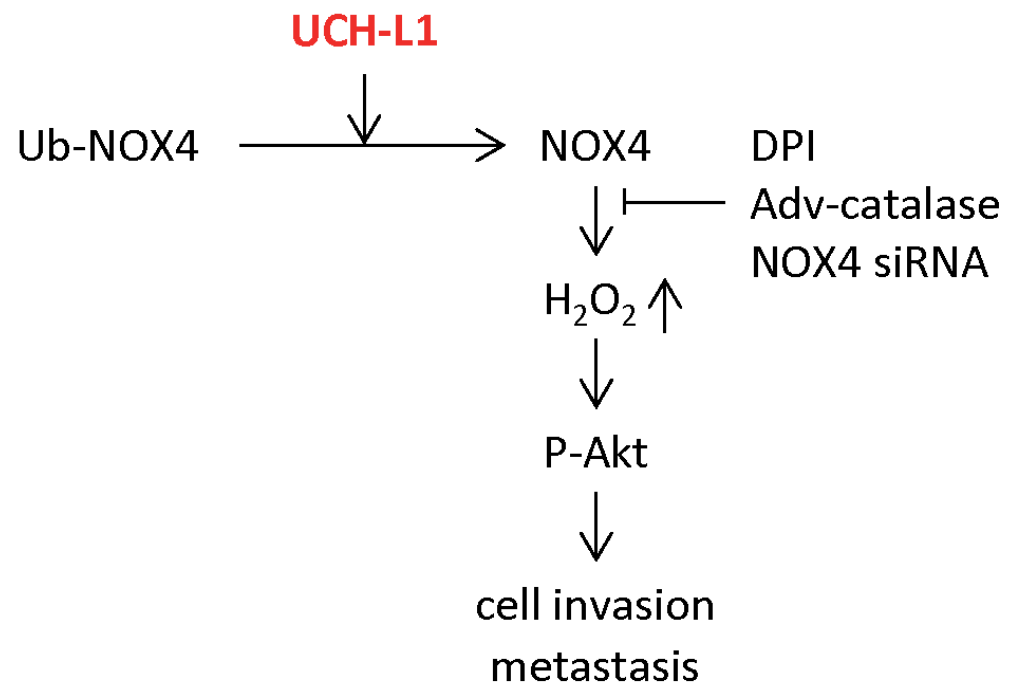

Figure 8: Suggested pathway linking UCH-L1-mediated $\mathrm{H}_{2} \mathrm{O}_{2}$ generation to increased cell invasion. 
the catalase (-/-) mouse model, we also demonstrated that UCH-L1-induced $\mathrm{H}_{2} \mathrm{O}_{2}$ acts as an essential metastatic factor in vivo.

\section{MATERIALS AND METHODS}

\section{Cell culture and transfection}

B16F10 melanoma and HeLa cells were grown at $37^{\circ} \mathrm{C}$ in DMEM and EMEM supplemented with 100 units $/ \mathrm{mL}$ of penicillin $\mathrm{G}, 100 \mu \mathrm{g} / \mathrm{mL}$ streptomycin and 10\% fetal bovine serum (all from Invitrogen: CA, USA), respectively. Use of human NOX4 expression plasmid, pcDNA3.0-V5-NOX4, was described in a previous report [36]. UCH-L1 was cloned into pcDNA3.1-myc/his(-)A vector (Invitrogen, CA, USA) to generate pcDNA3.1UCH-L1-myc. Transient transfections were performed using Effectene ${ }^{\circledR}$ transfection reagent (Qiagen, CA, USA) according to the manufacturer's instructions.

\section{Immunoprecipitation and western blot analysis}

Cells $\left(2 \times 10^{6}\right)$ were lysed in an IP buffer $(50 \mathrm{mM}$ Tris-HCl, $150 \mathrm{mM} \mathrm{NaCl}, 1 \mathrm{mM}$ EDTA (pH 7.4), 0.5\% sodium deoxycholate, $1 \%$ Triton $\mathrm{X}-100,0.1 \%$ SDS) containing protease inhibitor cocktail (Sigma-Aldrich, USA) and phosphatase inhibitors $\left(5 \mathrm{mM} \mathrm{Na}_{3} \mathrm{VO}_{4}\right)$ for 10 min on ice, sonicated for 5 seconds twice, and centrifuged at 12,000 rpm for $10 \mathrm{~min}$. The supernatant was incubated with anti-V5 antibody for $2 \mathrm{~h}$ at $4^{\circ} \mathrm{C}$ and then with protein G Sepharose ${ }^{\mathrm{TM}}$ affinity beads (GE Healthcare Bioscience $\mathrm{AB}$, Uppsala, Sweden) for $1 \mathrm{~h}$ at $4^{\circ} \mathrm{C}$. The beads were washed six times each with $1 \mathrm{~mL}$ of the IP buffer to remove nonspecific binding. The immune complex was solubilized in SDS gel sample buffer, separated by $10 \%$ SDS-PAGE, and detected with silver staining (Silver staining kit: GE Healthcare Bioscience AB, Uppsala, Sweden) or western blot analysis. Chemiluminescence signal was captured using LAS3000 system (Fujifilm, Japan) and each band was quantified using Multi Gauge V3.0 software (Fujifilm, Japan). The sources of antibodies used in this study were: anti-UCH-L1, and anti-myc antibodies - Millipore (MA, USA); anti-HA antibody - Roche (USA); anti-phosphoAkt (P-Akt), anti-phospho-p38 (P-p38), anti-phosphoERK (P-ERK) antibodies - Cell Signaling Technology (MA, USA); anti-V5 antibody - Invitrogen (CA, USA); anti- $\alpha$-tubulin antibody - Santa Cruz Biotechnology (CA, USA). Anti-NOX4 antibody was provided from YS Bae (Ewha Womans University, Korea) [48] or purchased from Abcam (Cambridge, USA) and Proteintech Group (IL, USA).

\section{Generation of B16F10 stable cell lines}

B16F10 cells stably overexpressing UCH-L1 were generated using LentiM1.4 lentiviral vector (Macrogen: Seoul, Korea). Cells were infected with lentiviral transduction particles carrying UCH-L1 sequence with C-terminal myc tag (Accession No. NM_004181) or with control lentiviral vector in complete culture medium with polybrene $(8 \mu \mathrm{g} / \mathrm{mL})$ for $5 \mathrm{~h}$. The cells were cultured for 7 days in puromycin-containing medium for selection. B16F10 cells with stable knockdown of UCH-L1 were generated using shLenti1.1 lentiviral vector (Macrogen: Seoul, Korea). Lentiviral transduction particles carrying shRNA sequence against UCH-L1 [49] or control nontarget sequence (AATCGCATAGCGTATGCCGTT) were used to knock down UCH-L1 expression. For selection, Zeocin ${ }^{\mathrm{TM}}$-containing culture medium was used for 14 days.

\section{Adenoviral-catalase infection}

B16F10 cells were infected with adenovirus encoding human catalase (Adv-catalase) or empty adenoviral vector (Adv-vector) (AbClon: Seoul, Korea) in DMEM containing $2 \% \mathrm{FBS}$, overnight at $37^{\circ} \mathrm{C}$. Catalase expression was monitored with anti-catalase antibody (AbClon: Seoul, Korea).

\section{Down-regulation of UCH-L1 using UCH-L1 specific siRNA}

UCH-L1 specific siRNAs were obtained from RNAi libraries predesigned by BIONEER Co. (Daejeon, Korea). Cat No. 1443992 for UCH-L1 siRNA \#1 (BIONEER, Korea); Cat No. 1443993 for UCH-L1 siRNA \#2 (BIONEER, Korea); Cat No. 1443994 for UCH-L1 siRNA \#3 (BIONEER, Korea); sense 5'-TTCTCCGAACGTGTCACGT-3' and antisense 5'-ACGTGACACGTTCGGAGAA-3' for control siRNA. Transfections with UCH-L1 siRNA \#1, 2 and 3 were carried out using Lipofectamine ${ }^{\circledR}$ RNAiMAX (Invitrogen: CA, USA) according to the manufacturer's protocol.

\section{Down-regulation of NOX4 mRNA and protein expression using NOX4 specific siRNA}

NOX4 specific siRNAs were obtained from YS Bae (Ewha Womans University, Korea) [50] and RNAi libraries predesigned by BIONEER Co. (Daejeon, Korea). These were designed as follows: sense 5'-GTAGGAGACTGGACAGAAC-3' and antisense 5'-GTTCTGTCCAGTCTCCTAC-3' for NOX4 siRNA \#1; Cat No. 1392780 for NOX4 siRNA \#2 (BIONEER, Korea); Cat No. 1392781 for NOX4 siRNA\#3 (BIONEER, 
Korea); sense 5'-TTCTCCGAACGTGTCACGT-3' and antisense 5'-ACGTGACACGTTCGGAGAA-3' for control siRNA. We ascertained the decreased levels of $\mathrm{H}_{2} \mathrm{O}_{2}$ in B16F10 cells transfected with NOX4 siRNA \#1, 2, or 3, using Amplex ${ }^{\circledR}$ Red hydrogen peroxide assay kit (data not shown). We used NOX4 siRNA\#1 for our study.

\section{Quantitative studies on real-time reverse transcription-polymerase chain reaction}

Total RNAs were extracted from cells with RNeasy ${ }^{\circledR}$ Mini Kit (Qiagen: Hilden, Germany) and reversetranscribed by SuperScript ${ }^{\mathrm{TM}}$ II reverse transcriptase with Oligo dT primers (Invitrogen: CA, USA). The resultant cDNAs for mouse NOX4 were quantitatively amplified with real-time RT-PCR using QuantiTect ${ }^{\circledR}$ Primer Assay kit (Cat No; QT00126042 for NOX4, Qiagen, Hilden, Germany) and DyNAmo ${ }^{\mathrm{TM}} \mathrm{HS}$ SBYR ${ }^{\circledR}$ green qPCR kit (Thermo scientific: MA, USA). Standard curve was obtained by plotting $\mathrm{Ct}$ (cycle threshold) values against log cDNA concentrations of five serial dilutions of the target nucleic acid. GAPDH was used as an internal control.

\section{Measurement of cellular ROS}

Cellular ROS levels were measured using the fluorescent dye, 2', 7'-dichlorodihydrofluorescein diacetate (CM-H $\mathrm{H}_{2} \mathrm{DCFDA}$ ) (Molecular Probes: OR,

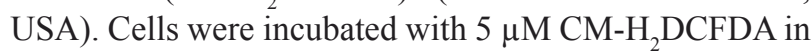
Hank's balanced salt solution (HBSS) at $37^{\circ} \mathrm{C}$ for $5 \mathrm{~min}$. The plate was mounted, and the DCF fluorescence images were immediately acquired by fluorescence microscopy, Axiovert 200 (Carl Zeiss: Jena, Germany). For flow cytometry, equal numbers of cells were harvested, washed with cold PBS, and treated with $3 \mu \mathrm{M}$ CM-H ${ }_{2}$ DCFDA in HBSS at $37^{\circ} \mathrm{C}$ for $15 \mathrm{~min}$ and the cellular ROS was immediately measured using FACSCalibur flow cytometer (BD Biosciences: NJ, USA). To quantify the log-amplified fluorescence which is emitted by cells, geometric mean (Geo Mean) of the fluorescence intensity as well as the Median value for the fluorescent peak was calculated by statistical analysis of BD CellQuest software. For the experiment using DPI, equal numbers of cells were treated with $20 \mu \mathrm{M}$ of DPI for $30 \mathrm{~min}$.

\section{Hydrogen peroxide $\left(\mathrm{H}_{2} \mathrm{O}_{2}\right)$-generating activity assay}

$\mathrm{H}_{2} \mathrm{O}_{2}$-generating activity was measured in intact cells using Amplex ${ }^{\circledR}$ Red hydrogen peroxide assay kit (Molecular Probes, OR, USA) [51]. Transfected cells $\left(2 \sim 3 \times 10^{5}\right)$ were added to $200 \mu \mathrm{L}$ of assay buffer $(25 \mathrm{mM}$ HEPES (pH 7.4) containing $0.12 \mathrm{M} \mathrm{NaCl}, 3 \mathrm{mM} \mathrm{KCl}, 1$ $\mathrm{mM} \mathrm{MgCl}, 0.1 \mathrm{mM}$ Amplex Red, and 0.032 unit HRP) and incubated for $60 \mathrm{~min}$ at $37^{\circ} \mathrm{C}$. Fluorescence intensity was measured using Molecular Devices Spectramax Gemini EM Fluorescence Microplate Reader (excitation wavelength: $544 \mathrm{~nm}$; emission wavelength: $590 \mathrm{~nm}$ ). For a positive control, $500 \mathrm{nM}$ of $\mathrm{H}_{2} \mathrm{O}_{2}$ in assay buffer was used. For a negative control, cells treated with $20 \mu \mathrm{M}$ DPI for $30 \mathrm{~min}$ were used.

\section{Cell invasion assay}

This was performed using a 24-well Transwell ${ }^{\circledR}$ unit with polycarbonate membrane (pore size, $8 \mu \mathrm{m}$ ) (Corning: NY, USA). The membrane was coated with Matrigel ${ }^{\mathrm{TM}}$ basement membrane matrix $(1 \mu \mathrm{g} / \mu \mathrm{L})$ (BD Bioscience, NJ, USA). Cells $\left(0.5 \sim 1 \times 10^{4}\right)$ were seeded into the upper chamber in a serum-free medium. The lower chamber was filled with a medium containing 10\% FBS. After incubation for $24 \mathrm{~h}$ at $37^{\circ} \mathrm{C}$, the cells on the upper side of membrane were removed with a cotton swab. The cells invading to the underside of the membrane were stained with $0.5 \% \mathrm{w} / \mathrm{v}$ Crystal violet in $25 \%$ methanol and counted at 100-fold magnification under a microscope (Carl Zeiss, Jena, Germany).

\section{Protein identification using nanoUPLC-ESI-q- TOF tandem MS}

To identify the proteins and modifications, the gels were destained and digested in gel with trypsin, and extracted as previously described [52]. The resulting peptides were dissolved in $10 \%$ acetonitrile containing $0.1 \%$ formic acid and subjected to nanoAcquity ${ }^{\mathrm{TM}}$ UPLC ${ }^{\text {TM} / E S I / q-T O F ~ t a n d e m ~ M S ~(S Y N A P T ~}{ }^{\mathrm{TM}}$ HDMS $^{\mathrm{TM}}$, Waters Co. UK), desalted on line using trap column (i.d. $180 \mu \mathrm{m} \times 20 \mathrm{~mm}$, Symmetry ${ }^{\circledR}$ C18) cartridge, and separated on a C18 reversed-phase $75 \mu \mathrm{m}$ i.d. $\times 200 \mathrm{~mm}$ analytical column $(1.7 \mathrm{~nm}$ particle size, BEH130 C18, Waters Co. UK) with integrated electrospray ionization PicoTip $^{\mathrm{TM}}(10 \mu \mathrm{m}$ i.d., New Objective, USA) using nanoAcquity ${ }^{\mathrm{TM}}$ UPLC/ESI/q-TOF MS/MS. Ten $\mu \mathrm{L}$ of peptide solutions in buffer A (water/formic acid; 100 : $0.1, \mathrm{v} / \mathrm{v})$, were injected onto a column and eluted by a linear gradient of $5-60 \%$ buffer B (ACN/formic acid; $100: 0.1, \mathrm{v} / \mathrm{v}$ ) over $100 \mathrm{~min}$. Initially, the flow rate was set to $250 \mathrm{~nL} / \mathrm{min}$ and a capillary voltage of $2.8 \mathrm{keV}$ was applied to the UPLC ${ }^{\mathrm{TM}}$ mobile phase before spray. Chromatography was performed on line to SYNAPTTM HDMS $^{\text {TM}}$. The mass spectrometer was programmed to record scan cycles composed of one MS scan followed by MSMS scans of the 3 most abundant ions in each MS scan. MS parameters for efficient data-dependent acquisition were: intensity $(>10)$, number of components to be switched from MS to MS/MS analysis. Tandem MS (MS/MS) spectra were matched against amino acid sequences in SwissProt human database (version 57.8., 
20401 entries) using Mascot search (version 2.2.06) and MOD $^{i}[53]$. The search parameters were: 0.3 Da tolerance for peptide and fragment ions; digestion with trypsin with up to one missed cleavage allowed. Acetylation (N-terminal), formylation (Lys), deamidation (Asn and Gln), oxidation (Met), phosphorylation (Ser, Thr, and Tyr), pyro-Glu modification (N-terminal Glu and N-terminal Gln), and ubiquitination (Lys) were the searched variable modifications.

\section{Confocal microscopy}

UCH-L1 overexpressing and control B16F10 cells were seeded on SecureSlip ${ }^{\text {TM }}$ Silicone Supported coverglass (Grace bio-labs: OR, USA). After fixing with 4\% paraformaldehyde in HBSS for $10 \mathrm{~min}$, cells were permeabilized by incubation with $0.1 \%$ Triton $\mathrm{X}-100$ in HBSS for $10 \mathrm{~min}$. To block non-specific protein adsorption, cells were treated with HBSS buffer containing $3 \%$ BSA, $0.2 \%$ Tween 20 , and $0.2 \%$ gelatine. Next, we used mouse monoclonal anti-myc antibody and AlexaFluor 568 conjugated goat anti mouse IgG (Molecular Probes: OR, USA) for UCH-L1-myc, and rabbit polyclonal anti-NOX4 antibody and AlexaFluor 488 conjugated goat anti-rabbit IgG (Molecular Probes: OR, USA) for NOX4. DAPI was used for nuclear staining. Images were taken at $40 \times$ magnification with a fluorescence confocal microscope, LSM510 (Carl Zeiss, Jena, Germany).

\section{Catalase (-/-) and catalase $(+/+)$ mice}

Specific pathogen-free, catalase (-/-) and catalase $(+/+)$ male mice, $8-10$ weeks old, were used in this study as described previously $[11,29]$. The housing, breeding, and experimental procedures were approved by the Animal Care Committees of Ewha Womans University (IACUC No.: ELAGC-07-1007) (Seoul, Korea).

\section{Pulmonary metastasis}

Pulmonary metastasis was deemed to have occured in the animals following i.v. injection of B16F10 mouse melanoma cells derived from C57BL/6J mice, when visible, black, and round-shaped colonies appeared on lung surfaces. Two weeks after i.v. injection of B16F10 cells, their lungs were extirpated, and the number of black spherical B16F10 colonies was counted. In the first set of experiments, UCH-L1-overexpressing or control B16F10 cells were infected with Adv-vector or Adv-catalase. The infected cells were trypsinized, and suspended in PBS. Cells $\left(1 \times 10^{6}\right)$ were injected intravenously into the tail veins of seven catalase $(+/+)$ and seven catalase (-/-) mice. In the second set of experiments, UCH-L1-knocked down or control B16F10 cells $\left(1.0 \times 10^{6}\right)$ were injected intravenously into the tail veins of male $\mathrm{C} 57 \mathrm{BL} / 6$ catalase $(+/+)$ and catalase $(-/-)$ mice. Seven catalase $(+/+)$ mice for control cells, five catalase $(+/+)$ mice for UCH-L1knocked down cells, seven catalase (-/-) mice for control cells, and seven catalase (-/-) mice for UCH-L1-knocked down cells were used.

\section{Statistical analysis}

Data are expressed as mean \pm standard deviation of the mean (SD) and analyzed using One-Way ANOVA on Originpro 7.5 software. A P value was derived to assess statistical significance.

\section{FINANCIAL SUPPORT}

This work was supported by the Global Research Lab Program (No. 2012K1A1A2045441) and by Proteogenomics Research Program (No. 2012M3A9B90036680) of NRF. H.J. Kim was supported by RP-Grant 2011 of Ewha Womans University. S. Kim was supported by Brain Korea 21 (BK21) Project.

\section{DISCLOSURE OF POTENTIAL CONFLICTS OF INTEREST}

No conflicts of interest, current or potential, exist on the part of any of the authors on any aspect of this study.

\section{REFERENCES}

1. Bacac M and Stamenkovic I. Metastatic cancer cell. Annu Rev Pathol. 2008; 3:221-247.

2. Friedl P and Wolf K. Tumour-cell invasion and migration: diversity and escape mechanisms. Nat Rev Cancer. 2003; 3:362-374.

3. Gupta GP and Massague J. Cancer metastasis: building a framework. Cell. 2006; 127:679-695.

4. Liotta LA. Cancer cell invasion and metastasis. Sci Am. 1992; 266:54-59, 62-63.

5. Fidler IJ. The pathogenesis of cancer metastasis: the 'seed and soil' hypothesis revisited. Nat Rev Cancer. 2003; 3:453-458.

6. Hart IR. 'Seed and soil' revisited: mechanisms of sitespecific metastasis. Cancer Metastasis Rev. 1982; 1(1):5-16.

7. Radisky DC, Levy DD, Littlepage LE, Liu H, Nelson CM, Fata JE, Leake D, Godden EL, Albertson DG, Nieto MA, Werb $\mathrm{Z}$ and Bissell MJ. Raclb and reactive oxygen species mediate MMP-3-induced EMT and genomic instability. Nature. 2005; 436:123-127.

8. Storz P. Reactive oxygen species in tumor progression. Front Biosci. 2005; 10:1881-1896. 
9. Droge W. Free radicals in the physiological control of cell function. Physiol Rev. 2002; 82:47-95.

10. Laurent A, Nicco C, Chereau C, Goulvestre C, Alexandre J, Alves A, Levy E, Goldwasser F, Panis Y, Soubrane $\mathrm{O}$, Weill B and Batteux F. Controlling tumor growth by modulating endogenous production of reactive oxygen species. Cancer Res. 2005; 65:948-956.

11. Kim YM, Kim KE, Koh GY, Ho YS and Lee KJ. Hydrogen peroxide produced by angiopoietin-1 mediates angiogenesis. Cancer Res. 2006; 66:6167-6174.

12. Finkel T. Redox-dependent signal transduction. FEBS Lett. 2000; 476:52-54.

13. Irani K. Oxidant signaling in vascular cell growth, death, and survival : a review of the roles of reactive oxygen species in smooth muscle and endothelial cell mitogenic and apoptotic signaling. Circ Res. 2000; 87:179-183.

14. Gregg JL, Turner RM, 2nd, Chang G, Joshi D, Zhan Y, Chen L and Maranchie JK. NADPH oxidase NOX4 supports renal tumorigenesis by promoting the expression and nuclear accumulation of HIF2Alpha. Cancer Res. 2014; 74:3501-3511.

15. Reddy MM, Fernandes MS, Salgia R, Levine RL, Griffin JD and Sattler M. NADPH oxidases regulate cell growth and migration in myeloid cells transformed by oncogenic tyrosine kinases. Leukemia. 2011; 25:281-289.

16. Wang J, Hong Z, Zeng C, Yu Q and Wang H. NADPH oxidase 4 promotes cardiac microvascular angiogenesis after hypoxia/reoxygenation in vitro. Free Radic Biol Med. 2014; 69:278-288.

17. Chen L, Xiao J, Kuroda J, Ago T, Sadoshima J, Cohen RA and Tong $\mathrm{X}$. Both hydrogen peroxide and transforming growth factor beta 1 contribute to endothelial Nox4 mediated angiogenesis in endothelial Nox4 transgenic mouse lines. Biochim Biophys Acta. 2014; 1842:24892499.

18. Yamaura M, Mitsushita J, Furuta S, Kiniwa Y, Ashida A, Goto Y, Shang WH, Kubodera M, Kato M, Takata M, Saida T and Kamata T. NADPH oxidase 4 contributes to transformation phenotype of melanoma cells by regulating G2-M cell cycle progression. Cancer Res. 2009; 69:26472654.

19. Bheda A, Shackelford J and Pagano JS. Expression and functional studies of ubiquitin C-terminal hydrolase L1 regulated genes. PLoS One. 2009; 4:e6764.

20. Ma YM, Zhao M, Zhong JL, Shi L, Luo Q, Liu JA, Wang J, Yuan XH and Huang CZ. Proteomic Profiling of Proteins Associated With Lymph Node Metastasis in Colorectal Cancer. Journal of Cellular Biochemistry. 2010; 110:15121519.

21. Rolen U, Freda E, Xie J, Pfirmann T, Frisan T and Masucci MG. The ubiquitin C-terminal hydrolase $\mathrm{UCH}-\mathrm{L} 1$ regulates B-cell proliferation and integrin activation. J Cell Mol Med. 2009; 13:1666-1678.

22. Tanaka T, Kuramitsu Y, Fujimoto M, Naito S, Oka M and
Nakamura K. Downregulation of two isoforms of ubiquitin carboxyl-terminal hydrolase isozyme L1 correlates with high metastatic potentials of human SN12C renal cell carcinoma cell clones. Electrophoresis. 2008; 29:26512659.

23. Tezel E, Hibi K, Nagasaka T and Nakao A. PGP9.5 as a prognostic factor in pancreatic cancer. Clin Cancer Res. 2000; 6:4764-4767.

24. Jang MJ, Baek SH and Kim JH. UCH-L1 promotes cancer metastasis in prostate cancer cells through EMT induction. Cancer Lett 2011; 302:128-135.

25. Kim HJ, Kim YM, Lim S, Nam YK, Jeong J and Lee $\mathrm{KJ}$. Ubiquitin C-terminal hydrolase-L1 is a key regulator of tumor cell invasion and metastasis. Oncogene. 2009; 28:117-127.

26. Ferraro D, Corso S, Fasano E, Panieri E, Santangelo R, Borrello S, Giordano S, Pani G and Galeotti T. Prometastatic signaling by c-Met through RAC-1 and reactive oxygen species (ROS). Oncogene. 2006; 25:3689-3698.

27. Feng XX, Liu M, Yan W, Zhou ZZ, Xia YJ, Tu W, Li PY and Tian DA. beta3 integrin promotes TGF-beta1/H2O2/ HOCl-mediated induction of metastatic phenotype of hepatocellular carcinoma cells by enhancing TGF-beta1 signaling. PLoS One. 2013; 8:e79857.

28. Hempel N, Bartling TR, Mian B and Melendez JA. Acquisition of the metastatic phenotype is accompanied by H2O2-dependent activation of the p130Cas signaling complex. Mol Cancer Res. 2013; 11:303-312.

29. Ho YS, Xiong Y, Ma W, Spector A and Ho DS. Mice lacking catalase develop normally but show differential sensitivity to oxidant tissue injury. J Biol Chem. 2004; 279:32804-32812.

30. Zhang C, Lan T, Hou J, Li J, Fang R, Yang Z, Zhang M, Liu $\mathrm{J}$ and Liu B. NOX4 promotes non-small cell lung cancer cell proliferation and metastasis through positive feedback regulation of PI3K/Akt signaling. Oncotarget. 2014; 5:4392-4405.

31. Boudreau HE, Casterline BW, Rada B, Korzeniowska A and Leto TL. Nox4 involvement in TGF-beta and SMAD3driven induction of the epithelial-to-mesenchymal transition and migration of breast epithelial cells. Free Radic Biol Med. 2012; 53:1489-1499.

32. Serrander L, Cartier L, Bedard K, Banfi B, Lardy B, Plastre O, Sienkiewicz A, Forro L, Schlegel W and Krause KH. NOX4 activity is determined by mRNA levels and reveals a unique pattern of ROS generation. Biochem J. 2007; 406:105-114.

33. Ambasta RK, Kumar P, Griendling KK, Schmidt HH, Busse R and Brandes RP. Direct interaction of the novel Nox proteins with p22phox is required for the formation of a functionally active NADPH oxidase. J Biol Chem. 2004; 279:45935-45941.

34. Martyn KD, Frederick LM, von Loehneysen K, Dinauer $\mathrm{MC}$ and Knaus UG. Functional analysis of Nox4 reveals 
unique characteristics compared to other NADPH oxidases. Cell Signal. 2006; 18:69-82.

35. von Lohneysen K, Noack D, Jesaitis AJ, Dinauer MC and Knaus UG. Mutational analysis reveals distinct features of the Nox4-p22 phox complex. J Biol Chem. 2008; 283:35273-35282.

36. von Lohneysen K, Noack D, Hayes P, Friedman JS and Knaus UG. Constitutive NADPH oxidase 4 activity resides in the composition of the B-loop and the penultimate $\mathrm{C}$ terminus. J Biol Chem. 2012; 287:8737-8745.

37. Bittencourt Rosas SL, Caballero OL, Dong SM, da Costa Carvalho Mda G, Sidransky D and Jen J. Methylation status in the promoter region of the human PGP9.5 gene in cancer and normal tissues. Cancer Lett. 2001; 170:73-79.

38. Reddy KB, Nabha SM and Atanaskova N. Role of MAP kinase in tumor progression and invasion. Cancer Metastasis Rev. 2003; 22:395-403.

39. Wu WS, Wu JR and Hu CT. Signal cross talks for sustained MAPK activation and cell migration: the potential role of reactive oxygen species. Cancer Metastasis Rev. 2008; 27:303-314.

40. Hurst-Kennedy J, Chin LS and Li L. Ubiquitin C-terminal hydrolase 11 in tumorigenesis. Biochem Res Int. 2012; 2012:123706.

41. Luanpitpong S, Talbott SJ, Rojanasakul Y, Nimmannit U, Pongrakhananon V, Wang LY and Chanvorachote P. Regulation of Lung Cancer Cell Migration and Invasion by Reactive Oxygen Species and Caveolin-1. Journal of Biological Chemistry. 2010; 285:38832-38840.

42. Ribeiro-Pereira C, Moraes JA, Souza Mde J, Laurindo FR, Arruda MA and Barja-Fidalgo C. Redox Modulation of FAK Controls Melanoma Survival - Role of NOX4. PLoS One. 2014; 9:e99481.

43. von Lohneysen K, Noack D, Wood MR, Friedman JS and Knaus UG. Structural insights into Nox4 and Nox2: motifs involved in function and cellular localization. Mol Cell Biol. 2010; 30:961-975.

44. Hsieh CH, Chang HT, Shen WC, Shyu WC and Liu RS. Imaging the impact of Nox4 in cycling hypoxia-mediated U87 glioblastoma invasion and infiltration. Mol Imaging Biol. 2012; 14:489-499.

45. Desai LP, Zhou Y, Estrada AV, Ding Q, Cheng G, Collawn JF and Thannickal VJ. Negative Regulation of NADPH Oxidase 4 by Hydrogen Peroxide-inducible Clone 5 (Hic5) Protein. J Biol Chem. 2014; 289:18270-18278.

46. Larsen CN, Price JS and Wilkinson KD. Substrate binding and catalysis by ubiquitin $\mathrm{C}$-terminal hydrolases: identification of two active site residues. Biochemistry. 1996; 35:6735-6744.

47. Li F, Wang H, Huang C, Lin J, Zhu G, Hu R and Feng $\mathrm{H}$. Hydrogen peroxide contributes to the manganese superoxide dismutase promotion of migration and invasion in glioma cells. Free Radic Res. 2011; 45:1154-1161.

48. Kim KS, Choi HW, Yoon HE and Kim IY. Reactive oxygen species generated by NADPH oxidase 2 and 4 are required for chondrogenic differentiation. J Biol Chem. 2010; 285:40294-40302.

49. Liu Y, Lashuel HA, Choi S, Xing X, Case A, Ni J, Yeh LA, Cuny GD, Stein RL and Lansbury PT, Jr. Discovery of inhibitors that elucidate the role of UCH-L1 activity in the H1299 lung cancer cell line. Chem Biol. 2003; 10:837-846.

50. Park HS, Chun JN, Jung HY, Choi C and Bae YS. Role of NADPH oxidase 4 in lipopolysaccharide-induced proinflammatory responses by human aortic endothelial cells. Cardiovasc Res. 2006; 72:447-455.

51. Nisimoto Y, Jackson HM, Ogawa H, Kawahara T and Lambeth JD. Constitutive NADPH-dependent electron transferase activity of the Nox4 dehydrogenase domain. Biochemistry. 2010; 49:2433-2442.

52. Jeong J, Jung Y, Na S, Lee E, Kim MS, Choi S, Shin DH, Paek E, Lee HY and Lee KJ. Novel oxidative modifications in redox-active cysteine residues. Mol Cell Proteomics. 2011; 10:M110 000513.

53. Na S, Jeong J, Park H, Lee KJ and Paek E. Unrestrictive identification of multiple post-translational modifications from tandem mass spectrometry using an error-tolerant algorithm based on an extended sequence tag approach. Mol Cell Proteomics. 2008; 7:2452-2463. 